\title{
PATCHY INVASION AND THE ORIGIN OF A HEMLOCK-HARDWOODS FOREST MOSAIC
}

\author{
Margaret B. Davis, ${ }^{1}$ Randy R. Calcote, ${ }^{1}$ Shinya Sugita, ${ }^{1}$ and Hikaru Takahara ${ }^{2}$ \\ 'Department of Ecology, Evolution and Behavior, University of Minnesota, Saint Paul, Minnesota 55108 USA \\ ${ }^{2}$ University Forest, Kyoto Prefectural University, Kyoto 606, Japan
}

\begin{abstract}
The record of forest invasion by eastern hemlock (Tsuga canadensis) during the course of Holocene migration provides useful information about invasion processes in temperate forest, a system that has been invaded by few exotic species. We used fossil pollen preserved in small forest hollows, which record forest composition on the scale of 1-3 ha, to study hemlock invasion of forests in the Sylvania Wilderness in the upper peninsula of Michigan, where there is now a mosaic of $3-30$ ha stands dominated either by hemlock or by sugar maple (Acer saccharum) and basswood (Tilia americana). Fossil pollen was interpreted by comparison with 66 surface samples from small hollows in Michigan and Wisconsin, using three different statistical methods: pollen ratios, a dissimilarity index, and canonical variates analysis (CVA) ordination. We found that four hemlock stands along a $10-\mathrm{km}$ transect across Sylvania originated as patches of white pine (Pinus strobus) forest that were invaded by hemlock $-3000 \mathrm{yr}$ ago (calibrated ${ }^{14} \mathrm{C}$ dating) when hemlock expanded its range in northern Michigan. Invasion occurred at about the same time (within $800 \mathrm{yr}$ ) at all sites but was not associated with disturbance at any site. Over the next several thousand years hemlock coexisted with white pine, but eventually, at a time that differs from site to site, hemlock became dominant, and white pine disappeared from all but one of the four stands. These changes were apparently driven by climate changes over the last $4000 \mathrm{yr}$ that caused the water table to rise (Brugam and Johnson 1997). The history of four nearby maple stands is more variable and less well understood. Unlike the hemlock stands, three of the four maple patches were not dominated by pine at the time of hemlock invasion, but instead had abundant oak (Ouercus) and/or maple. Two of these stands were not invaded by hemlock, and the third, if invaded at all, was invaded for a few centuries by low densities of hemlock trees. Thus invasion by hemlock was sensitive to the species composition of the resident forest. Sugar maple and basswood increased in these stands, and by 2000 to $800 \mathrm{yr}$ ago, depending on site, they resembled modern maple stands. The fourth patch was invaded by hemlock, but it was converted to a maple stand 1000-500 yr ago. A wood layer in the sediment is evidence that a catastrophic windstorm may have been responsible.
\end{abstract}

Key words: forest mosaic; forest history; fossil pollen; hemlock hardwoods: hollows; Holocene; invasion: Michigan: Sylvania: Tsuga canadensis.

\section{INTRODUCTION}

There is a large literature on species invasions and the characteristics of invasible communities (Elton 1958, Mooney and Drake 1986, Drake et al. 1989. Lodge 1993a). These studies show that temperate forest communities, especially late-successional "mature", forest, have been invaded by relatively few exotic plants (Crawley 1987, Rejmanek 1989). Yet we know that temperate forests were invaded by many native species in the course of the Holocene as trees extended ranges northward after the continental ice sheet started to retreat $14000 \mathrm{yr}$ ago (Davis 1976, 1981, Webb 1988). After the first wave of spruce and aspen, almost all of the migrating trees were expanding in landscapes that were already forested. How did these trees invade

Manuscript received 17 March 1997; revised 22 November 1997; accepted 23 December 1997; final version received 19 January 1998 established forests that now appear resistant? The fossil record is important as a source of information about invasion processes in these communities (Lodge $1993 b$ ), information that is critical in predicting responses to future climate change.

Many studies of Holocene tree migration describe range extension at the regional scale (Davis 1976, 1981, Huntley and Birks 1981, Huntley 1988, Webb 1988), but recent work addresses invasion at the stand scale. For example, beech (Fagus sylvatica) migrated northward into Scandinavia in the first millennium AD. Fossil pollen preserved in small ponds and forest hollows, which provide a stand-scale vegetation record, shows that invasion by beech and its replacement of lime (Til$i a$ ), which had been dominant, was correlated with human disturbance (Andersen 1973, 1988, Aaby 1988). Bjorkman (1996) uses a pair of hollows to show that in one forest stand, which was heavily disturbed, beech invaded and became dominant at $A D \sim 500$. The stand 
is dominated by beech today. A second stand was invaded by beech at about the same time, but the level of disturbance was much lower, and beech coexisted with lime in a mixed stand until the forest was cut $\sim 200$ yr ago.

In this paper we use a similar approach to study the invasion of forests by eastern hemlock (Tsuga canadensis) 3200 years ago (Davis 1987). Pollen diagrams are described from small forest hollows in eight forest stands within the Sylvania Wilderness in northern Michigan. The old-growth forest there is patchy, with large (3-30 ha) stands dominated by hemlock or by hemlock's major competitor, sugar maple (Acer saccharum). The hollows we consider in this paper are from relatively large patches. Thus the forest surrounding each hollow documents the eventual outcome of hemlock invasion at that site; four of the eight patches are currently dominated by hemlock and the other four by sugar maple (Frelich et al. 1993). The fossil pollen in the sediment records two different trajectories of change: hemlock entry to the stand, or a contrasting record of changes within a forest that was not invaded by hemlock.

In comparing the histories of these eight forest patches we consider here two categories of questions of general importance to forest invasion. The first concerns the timing of hemlock invasion into Sylvania forests. Timing might have been simultaneous everywhere if a migration front reached Sylvania, or varying if outlying colonies later coalesced into a continuous population (Shigesada and Kawasaki 1997, Davis and Sugita 1996). Both of these migration scenarios assume a uniform environment in which colony locations are determined by chance seed dispersal. Alternatively, physical environment could have been important, especially $3000 \mathrm{yr}$ ago, when the climate was more xeric (Frelich et al. 1993). If moisture limitations were more important than chance dispersal in governing the locations of colonies, hemlock might have first established in wet sites, expanding onto xeric locations hundreds or even thousands of years later, after the climate had become more moist. A second series of questions concerns invasibility of the resident forest community. The ease of hemlock invasion could have been affected by the species composition of the resident forest. We addressed this question by comparing pollen assemblages that were deposited just before hemlock entry at all the hollows. Consistent differences between stands that were invaded and stands that were not invaded would suggest that vegetation composition was important. This result is confounded by the role of the physical environment, however, because community composition is often correlated with environmental differences that could have affected hemlock directly. In addition, disturbance appears to change resident communities in ways that increase the success of invaders (Fox and Fox 1986, Crawley 1987, Rejmanek 1989), and we inspected our data carefully for evidence of disturbance,

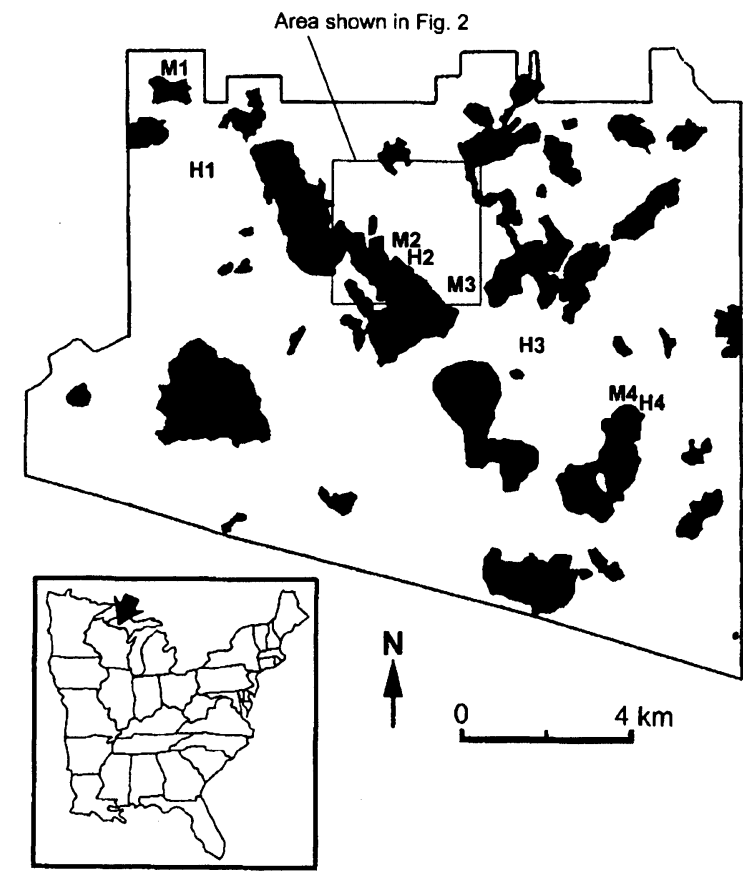

FIG. 1. Map of Sylvania, showing locations of sites. Inset shows location of Sylvania within the eastern United States. Sites are: Whitefish Hemlock (H1), Plot A Hemlock (H2), Plot C Hemlock (H3), Deer Island Hemlock (H4), Snapjack Hardwoods (M1), Plot A Hardwoods (M2), Crooked-Clark Lake Hardwoods (M3), and Deer Island Hardwoods (M4). Lakes are solid black.

by fire or by wind, at the time of hemlock invasion. Northern Michigan was only sparsely populated by hunting and gathering Late Archaic people at the time of hemlock invasion, so disturbance of the forest by humans is unlikely (Fitting 1975).

Our data set of 10 sediment cores from small hollows is unusually large, providing information about forest history of eight forest patches along a $10-\mathrm{km}$ transect. Because pollen representation is influenced by differences in production and dispersal, our interpretations are based on comparisons with 66 surface samples from forest hollows in Michigan and Wisconsin. Three different statistical methods were used to compare the fossil data with pollen assemblages in the surface samples. Because each of the surface samples is accompanied by counts of all the trees in the surrounding 3 ha, our interpretations of the fossil records take the form of detailed comparisons with modern forests.

\section{Study Area and Climate History}

Our studies were carried out in the 8500-ha Sylvania Wilderness (U.S. Forest Service) in northern Michigan (Fig. 1). The uplands within the Wilderness support old-growth hemlock-hardwoods forest. The forest is patchy on the scale of 3-30 ha, with hemlock dominant in some stands and sugar maple (Acer saccharum) and 
FIG. 2. Leaf-off enhanced infrared aerial photograph of old-growth forest in a part of the Sylvania Wilderness. Dark patches are hemlock stands; light patches are sugar maple-basswood stands; medium gray fine-textured patches are bogs; black areas are lakes. The mapped plot described in Frelich et al. (1993) is outlined in white.

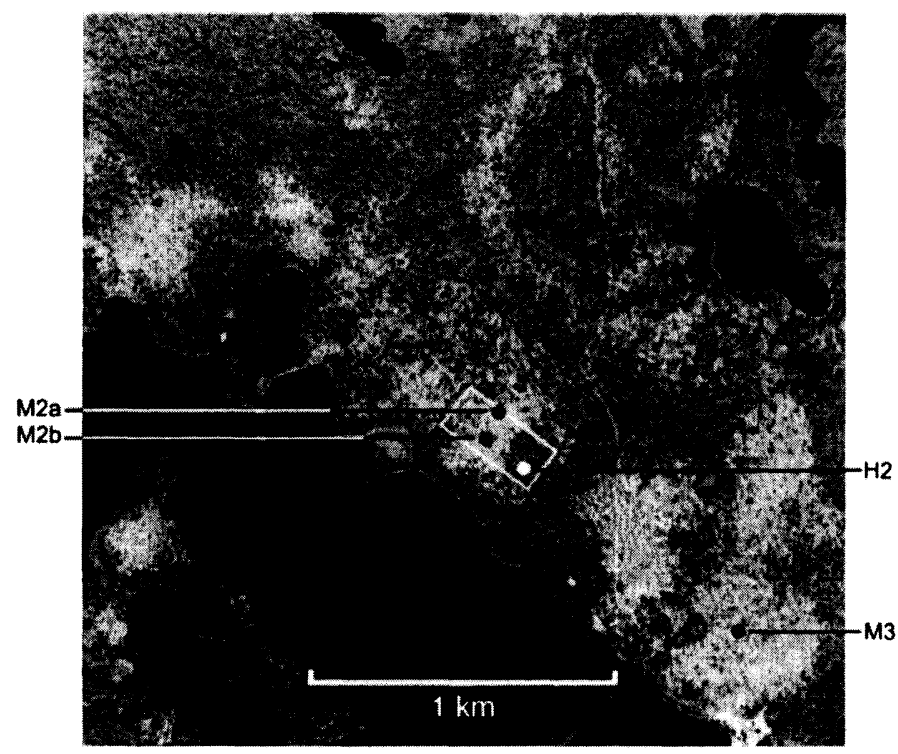

basswood (Tilia americana) dominant in others (Fig. 2). Yellow birch (Betula allegheniensis) grows in both stand types, although it is more abundant in hemlock stands. Black ash (Fraxinus nigra) often occurs in hollows. White pine (Pinus strobus) is uncommon in upland areas although it does occur in some hemlock stands. White pine is found more often in conifer stands along the shores of lakes, where it grows with hemlock, white cedar (Thuja occidentalis), and red pine (Pinus resinosa). The Sylvania forests were selectively logged for white pine around the turn of the century, but presumably the upland forests, where white pine is rare, were little disturbed by this process. Many trees in our mapped plots are several hundred years old, attesting to the continuity of the upland forest (Frelich and Graumlich 1994, Parshall 1995).

Using aerial photographs and GIS, Pastor and Broschart (1990) estimated that hemlock stands occupy $37 \%$ of the area of Sylvania, hardwood stands $11.7 \%$, and mixed stands $17.1 \%$. Spruce (Picea glauca and P. mariana), fir (Abies balsamea), and larch (Larix laricina) on bogs comprise $8 \%$ of the area, and lakes and nonforested wetlands $26 \%$. GIS analysis failed to identify significant differences in soils, slope, or aspect that are correlated with the distributions of hemlock stands or hardwood stands, although there is association of mixed stands with medium sand (largely due to one large mixed stand) (Pastor and Broschart 1990). Detailed studies of soil profiles within a mapped 7-ha plot failed to demonstrate differences between a hemlockdominated area and a hardwood-dominated area (Frelich et al. 1993). Within these stands, however, canopy composition and litter chemistry affect the microclimate, light environment, humus type, and humus thickness, as well as nutrient availability (Ferrari 1993). These feedbacks result in distributions of seedlings and subcanopy sugar maple and hemlock saplings that are spatially correlated with canopy trees of the same species (Frelich et al. 1993, Davis et al. 1994). Positive neighborhood feedbacks on recruitment appear to reinforce the continued dominance of hemlock and sugar maple in their respective patches (Ferrari 1993, Frelich et al. 1993).

During the last $4000 \mathrm{yr}$ climate changes have resulted in a rise of the regional groundwater table. The resulting rise in lake levels was especially rapid between $\sim 4300$ and 3200 calendar years ago, but continued at a slower rate to the present (Brugam and Johnson 1997). During this same period summers may have been growing cooler and winters warmer as a result of orbital forcing (Bartlein et al. 1984, COHMAP 1988). These changes in climate apparently favored hemlock, which extended its range westward across upper Michigan and northern Wisconsin, invading Sylvania forests $\sim 3200$ yr ago. Yellow birch, sugar maple, and basswood, which were already present in Sylvania forests, were also favored by the change in climate, increasing in abundance. Eventually the pine-oak-red maple forests within Sylvania were replaced by a mosaic of stands dominated by hemlock or by hardwoods (Brugam et al. 1997).

\section{METHODS \\ Small hollows}

Sylvania is located on the 12000 -yr-old Winegar terminal moraine (Attig et al. 1985). The moraine is predominantly sandy loam, but it is variable in texture and apparently contained many fragments of buried glacial ice, because the surface is irregular with numerous small potholes and kettles. Many of these depressions are dry all or part of the year, while others, the small 


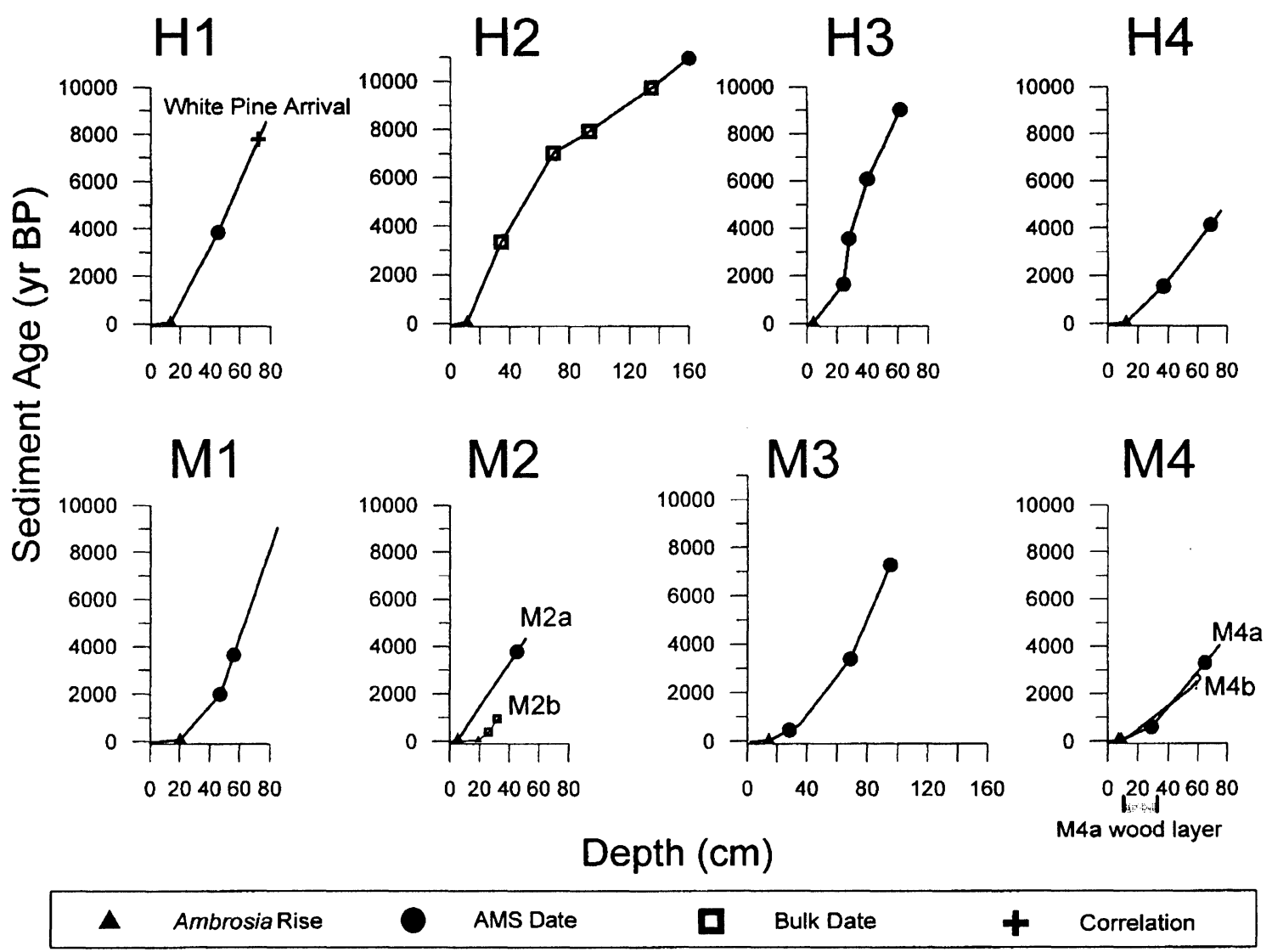

FIG. 3. Age-depth curves for the 10 sediment profiles

forest hollows that serve as sedimentary basins for the present study, remain damp year-round, preserving organic sediment. In a few hollows, sediment accumulation began in the late glacial, with the oldest pollen assemblages recording tundra vegetation before the arrival of spruce (Davis et al. 1992). Others are much younger, with inception of sediment accumulation 6000,3500 , or $1200 \mathrm{yr}$ ago. At all of the hollows we have studied, once organic sediment accumulation began, it apparently continued without interruption, in apparent response to a continuously rising water table (Brugam and Johnson 1997). The sediment accumulation rate was slow $(1-3 \mathrm{~cm} / 100 \mathrm{yr})$ but pollen concentrations are high $\left(>10^{6}\right.$ grains $\left./ \mathrm{cm}^{3}\right)$ and preservation is fair to good.

The hollows used for study are in forest patches along a transect $10 \mathrm{~km}$ in length (Fig. 1). Fossil pollen analyses from four different hemlock patches $(\mathrm{H} 1, \mathrm{H} 2$, $\mathrm{H} 3$, and H4) were compared with pollen records from four maple patches (M1, M2, M3, and M4). Two hollows were cored in two of the maple stands (cores M2a, M2b, M4a, and M4b). Hemlock/sugar maple pollen ratios for several of these sites were given in Davis et al. 1994, with Ml referred to as "Snapjack hardwoods," H1 as "Long lake hemlock," M2b as "Plot
A hardwoods," $\mathrm{H} 2$ as "Plot A hemlock," M3 as "Clark-Crooked lake hardwoods," and H3 as "Plot C hemlock."

Sediment was collected in $10 \mathrm{~cm}$ diameter cores with a piston corer with saw teeth at the bottom. The cover was rotated into the sediment, sawing through any coarse plant debris encountered. In the laboratory, subsamples representing $0.5-1.0 \mathrm{~cm}$ of sediment depth were prepared for pollen analysis using standard $\mathrm{KOH}$, $\mathrm{HF}$, and acetolysis procedures (Berglund and RalskaJasiewiczowa 1986). Peaty layers with coarse plant debris were screened to remove large plant fragments. Pollen and charcoal concentrations were calculated using marker Lycopodium spores added to the sediment samples prior to preparation (Stockmarr 1971). Charcoal fragments $>100 \mu \mathrm{m}^{2}$ were measured in the pollen preparations using an image analysis system.

Sediment age was established for each core by plotting depth against the calibrated radiocarbon age (Stuiver and Reimer 1993, Fig. 3) of seeds of terrestrial plants or charcoal fragments isolated from the sediment. The date for the rise of pollen from ragweed (Ambrosia) and other weeds near the top of each core was set at AD 1890, as this is the date of the white pine harvest in this part of Michigan. We lack sufficient 


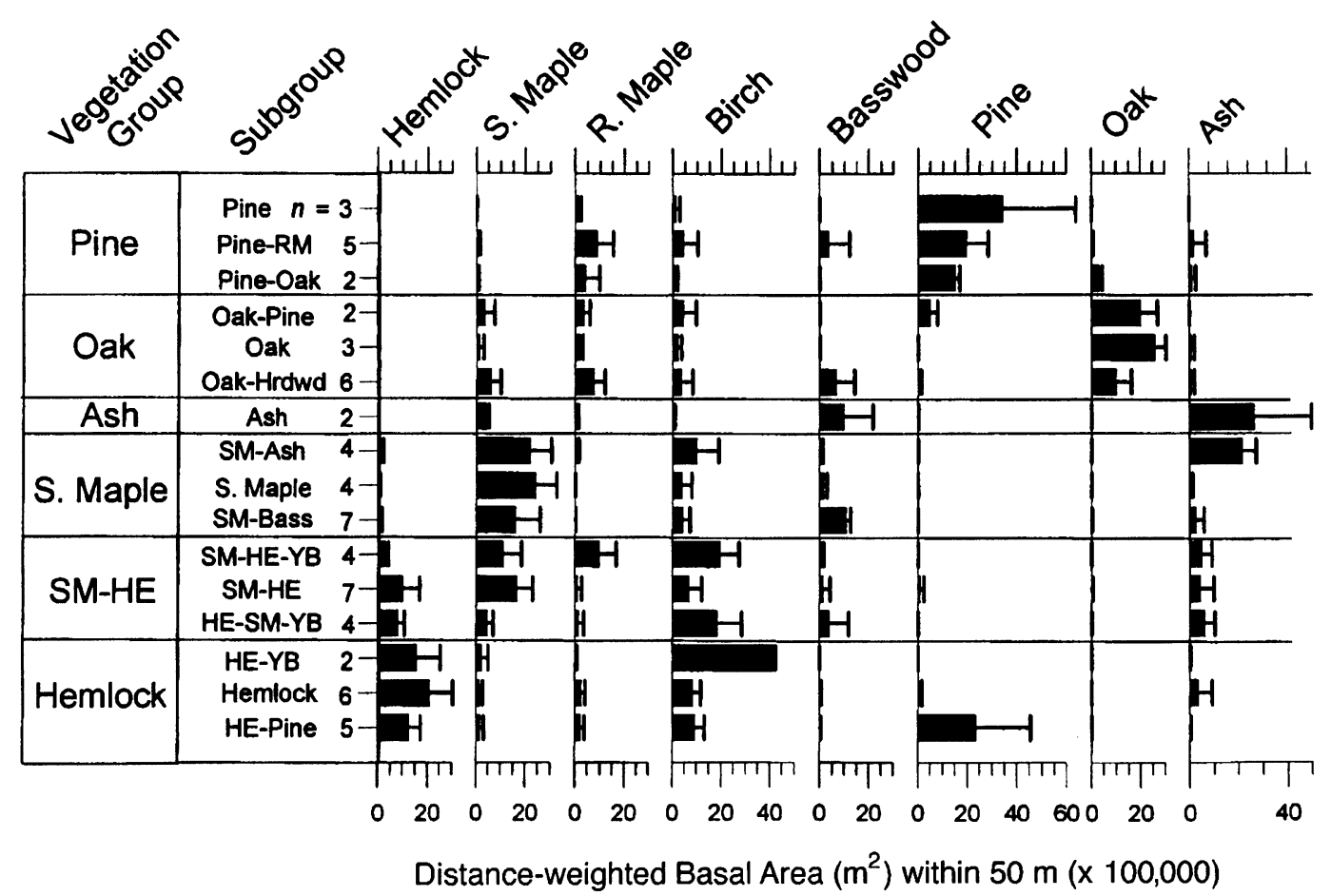

FIG. 4. Histograms showing species abundances of the eight most abundant taxa within $50 \mathrm{~m}$ of surface sampling sites in northern Michigan and Wisconsin. Tree basal area, weighted for distance, is averaged for each vegetation subgroup; error bars show standard deviations. See Calcote (1998) for vegetation composition at each site.

dates to determine short-term variations in sedimentation rate, and consequently we do not present data calculated as pollen accumulation rates.

\section{Interpretation of fossil pollen}

The forest stand surrounding a hollow has a major influence on the quantities of pollen deposited in the sediments. Because of the leptokurtic nature of pollen dispersal, trees within $50 \mathrm{~m}$ of a hollow are much better represented by pollen than trees $\geq 100 \mathrm{~m}$ distant (Andersen 1970, Prentice 1985, Sugita 1993, 1994, Calcote 1995). The relationship between species abundance in the vegetation and pollen abundance in the sediment is affected by pollen productivity and dispersal characteristics, which vary with taxon. Our interpretation of fossil pollen is, therefore, based on methods of calibrating relative pollen abundances in sediments using 66 surface pollen assemblages from small hollows in northern Michigan and adjacent Wisconsin (Calcote 1995, 1998). Each surface sample is accompanied by basal area measurements of all canopy trees within 50 $\mathrm{m}$. The vegetation data were classified into six major stand types, and five of these types were further subdivided (Fig. 4; see Calcote 1998 for details). For example the first five samples of the hemlock group shown at the bottom of Fig. 4 have abundant white pine as well as hemlock trees, the next six are dominated by hemlock, while the last two have abundant yellow birch (Fig. 4).

Numerical methods appropriate for interpretation of fossil pollen assemblages from small forest hollows are discussed in detail by Calcote (1998). In this paper we use three of the methods he recommends:

a) Squared chord distance is a measure of the degree of dissimilarity between two assemblages (Prentice 1980, Overpeck et al. 1985). Fossil pollen assemblages that are similar to modern assemblages are assumed to have been produced by similar vegetation. The critical value of this index used to determine modern pollen assemblages that are good analogs for a fossil sample depends on the particular data set and number of taxa used and is somewhat subjective (Overpeck et al. 1985, Anderson et al. 1994). We used the 13 arboreal taxa abundant in the vegetation surrounding the 66 surface samples to calculate squared chord distance between each fossil sample and [the pollen of] each surface assemblage. We used distances $<0.05$ to indicate pollen assemblages that are likely to be from the same stand type, and distances $>0.05$ but $\leq 0.1$ as a weak analog for the fossil sample but still able to provide some insight into the type of vegetation that produced the fossil pollen assemblage. When the distance is large $(>0.1)$, we considered the dissimilarity so great that there is little information in the comparison (Calcote 1998). 
b) Canonical variates analysis (CVA), a form of multiple discriminant analysis, is an ordination method that maximizes differentiation of a priori groups (Prentice 1980, Birks and Gordon 1985), making it appropriate for these surface pollen assemblages, which are assigned to groups based on tree species abundance within $50 \mathrm{~m}$. CVA was used to ordinate the modern pollen assemblages into the groups assigned from vegetation data. CVA separated the surface pollen assemblages into six groups corresponding to the six major stand types, with the first two CVA axes explaining $83 \%$ of the variance. Areas in the ordination space that are labeled as indicating a particular vegetation assemblage were drawn to include all surface samples from that stand type (Calcote 1998). Fossil pollen proportions (based on the sum of 13 taxa used in squared chord distance) were interpolated to $100-\mathrm{yr}$ intervals using rectangular integration (Davis 1973) and projected into this space in order to determine which stand types they resemble through time. Because fossil pollen samples cannot be included in the ordination with the surface pollen samples using CVA, it is possible that a fossil sample may fall near a stand type without being similar to it (Jacobson and Grimm 1986). Caution must be used, therefore, in interpreting the ordinations in the case of fossil samples that do not have analogs in the surface sample collection, as indicated by squared chord distance.

c) Hemlock: sugar maple ratio. Ratios of pollen types can be useful in interpreting fossil pollen assemblages, because they can focus on the relative abundance of two types that are important to a particular question (Tsukada 1958, Maher 1963, Davis et al. 1994, Lynch 1996). The ratio of hemlock to sugar maple pollen differs between modern stands at Sylvania that are dominated by hemlock and sugar maple (Davis et al. 1994) and therefore can be used to indicate the relative abundance of these taxa in a stand. Ratios should be used only after general forest composition is known from analogs (Calcote 1998). In surface samples ratios $<3$ are characteristic of sugar maple stands, ratios $>3$ and $<6$ are characteristic of mixed stands, though also found in some hemlock stands, and ratios $>6$ are found only in hemlock-dominated stands (Calcote 1998).

\section{RESULTS}

Detailed diagrams of pollen percentages plotted against the age of the sediment are shown in Fig. 5 for two of the sites, a hemlock hollow (H2) and a maple hollow (M3). Pollen diagrams from the other hollows are shown in Fig. 6, but to save space, fewer pollen types are shown.

Features common to all the pollen diagrams (Figs. 5 and 6 ) reflect regional vegetation changes similar to those found by Brugam et al. (1997). Pine pollen percentages, primarily white pine, are high from 8000 to $3000 \mathrm{yr}$ ago, with pollen of oak and red maple relatively abundant. Herbs such as grass (Poaceae) and ragweed
(Ambrosia) make up several percentage points. Sugar maple pollen is present but uncommon (generally $<1$ $2 \%$ ) before $3000 \mathrm{yr}$ ago, and pollen from other deciduous trees, such as basswood and ironwood (Ostrya virginiana), is present in only trace amounts. Charcoal abundance is variable between hollows, but generally has highest levels in the older sediment, with a decline after $3000 \mathrm{yr}$ ago.

In contrast, sediments younger than $3000 \mathrm{yr}$ show declining pine pollen, and increasing pollen from hemlock and northern hardwoods such as birch, sugar maple, and basswood. Birch pollen percentages increase around $4000 \mathrm{yr}$ ago, and percentages are variable from level to level. Spruce and fir pollen percentages also increase in younger sediment (Fig. 5).

In addition to the overall similarity between the pollen diagrams, there are subtle differences due to differences in composition between stands. These are discussed with the aid of multivariate methods and pollen ratios designed to help tease out the local pollen signal from the regional pollen rain.

Hemlock hollows.-At the three hemlock hollows where sediment began accumulating before $6000 \mathrm{yr} \mathrm{BP}$, fossil assemblages 8000-5000 yr BP resemble surface samples from pine-dominated forests (Fig. 7a). For an interval of a few hundred to a thousand years, around $4000 \mathrm{yr} \mathrm{BP}$, pollen assemblages at $\mathrm{H} 2$ and $\mathrm{H} 3$ resemble surface samples from oak-dominated forests. Analogs during this time are from the pine-oak, pine-red maple, and oak-hardwood subgroups (Fig. 7a). This change is reflected in the pollen diagrams by declining pine and slightly higher oak, and sometimes sugar maple and birch pollen percentages (Figs. 5 and 6), reflecting increased abundance of hardwoods in these stands for varying lengths of time.

In $\mathrm{H} 2$ the squared chord distance indicates similarity to pine stands again by $3500 \mathrm{yr}$ BP (Fig. 7a). The reestablishment of pine is weakly suggested at $\mathrm{H} 3$ by a single sample $3600 \mathrm{yr} \mathrm{BP}$, and at $\mathrm{H} 4$ by weak pine analogs 3000 yr BP. Ordination trajectories are consistent with this interpretation, moving farther into the overlap space between pine and oak stands, then returning to the region of pine stands before hemlock invasion $(\mathrm{H} 2, \mathrm{H} 3, \mathrm{H} 4$, Fig. 8a). $\mathrm{H} 1$ has close analogs in modern pine stands from 6000 to $4000 \mathrm{yr} \mathrm{BP}$, but then has no close analogs for several hundred years, roughly corresponding to an ash peak about $3000 \mathrm{yr}$ BP ("Other Trees," Fig. 6), making interpretation of analogs and CVA trajectories problematic.

Pollen assemblages change to resemble surface samples from modern hemlock stands with a large component of white pine between 3500 and $2600 \mathrm{yr}$ BP (Figs. 4 and $7 \mathrm{a}$ ). This change, indicating invasion of each of these stands by hemlock (as well as a change in the regional pollen signal), occurs rapidly, apparently within a few centuries at any single site (Figs. 5 , 6 , and 7a). Similarity to surface samples from modern hemlock stands without white pine increases at differ- 
ent times at the different hemlock stands, but hemlock : sugar maple pollen ratios at hemlock sites remain high (well above 3) from $3000 \mathrm{yr}$ BP to the present, indicating hemlock dominance relative to maple throughout this period in all four stands (Fig. 9).

Pollen assemblages at $\mathrm{H} 3$ change from hemlock-pine to hemlock assemblages $1500 \mathrm{yr}$ ago, $\sim 300$ years after the only clear charcoal peak that was found in any of these cores after $3000 \mathrm{yr}$ ago (Figs. 6 and 7a). (This was apparently a local fire event, as the same charcoal peak did not occur in a hollow only $100 \mathrm{~m}$ distant [Davis et al. 1994: Fig. 2.6]). At $\mathrm{H} 1$ and H4, the shift from hemlock-pine to hemlock begins $\sim 1500-1000 \mathrm{yr}$ ago and is less clear than at $\mathrm{H} 3$. At $\mathrm{H} 2$, the shift from mixed hemlock-white pine to hemlock does not occur until the last few samples (Fig. 7a), showing little change until the end of the 19 th century AD when large pines were removed from the adjacent bog. $\mathrm{H} 2$ lies at the edge of an area shown on the U.S. Forest Service forest cover-type map as "Hemlock-hardwoods-white pine." Several white pine canopy trees grow near the hollow, and white pine makes up $6 \%$ of the basal area in the swamp around the hollow (Frelich et al. 1993).

Maple hollows. - The vegetation history around the maple hollows is less well understood, because there are fewer analogs to surface sample assemblages (Fig. $7 b)$. M3 starts out with a history similar to hemlock hollows, with pollen in sediment dating from 6000 to $4000 \mathrm{yr}$ BP analogous to surface samples from pine forests, but after $4000 \mathrm{yr}$ BP there is only a slight resemblance to assemblages from pine stands (Fig. $7 \mathrm{~b}$ ). The best analogs at M3 $3800 \mathrm{yr}$ BP are from the oakhardwood subgroup, followed by an extended period without clear analogs. The only other maple hollow with sediment dating back beyond $6000 \mathrm{yr}$ BP is M1, which has weak analogs to pine stands until $\sim 3000 \mathrm{yr}$ ago, but has no strong analogs during this period. Pollen assemblages at M1 during this time have high percentages of both white pine and sugar maple (Fig. 6), suggesting a mixed forest of a type not represented in our surface samples, or a combination of stand composition and background pollen not represented in our surface samples (T. E. Parshall and R. Calcote, unpublished data).

None of the four maple stands have strong analogs to pine stands between 3600 and $3000 \mathrm{yr}$ BP, the period when hemlock invades three of the four hemlock stands. Analogs at two stands (M3 and M4a) suggest that they were more similar to oak-hardwood stands. The lack of strong analogs for these stands at the time of hemlock invasion of nearby forest means that we cannot reconstruct the vegetation around these sites at the time. However, the vegetation around these hollows was different from the stands surrounding the hemlock hollows, three of which have analogs in pine forest during this period. The CVA ordinations (Fig. 8b) suggest that the vegetation at two of the maple hollows (M1 and M3) was in a region of the ordination space closer to oak assemblages at the time the trajectories shift to the right $\sim 3000 \mathrm{yr}$ ago), while assemblages from three of the hemlock hollows $(\mathrm{H} 1, \mathrm{H} 2, \mathrm{H} 3)$ were more similar to pine stands (Fig. 8a). Interpretations of the ordination results for maple stands during this time are, however, uncertain, because the lack of analogs could result in spurious associations in ordination space.

Hemlock : sugar maple pollen ratios at all of the hollows except M4, however, remain low, generally $<3$, throughout the last $3000 \mathrm{yr}$, indicating high maple abundance relative to hemlock throughout this period, and showing that the late-Holocene histories of all of these stands except M4 were very different from hemlock stands (Fig. 9). After 3000 yr BP there are still few strong analogs for the hardwood hollows. Weak analogs suggest that M3 and M4 may have had pine and/or hemlock around them between 3000 and 2000 yr BP (Fig. 7b), but the analogs are not as strong, or as long-lasting, as those for hemlock hollows (at least $\mathrm{H} 2$ and $\mathrm{H} 3$ ) during this period. Hemlock pollen percentages show a weak peak at M1 during this period, and only a single sample peak at M4 (Fig. 6). Ordination trajectories also suggest that hardwood stands may have had hemlock in the stands during this period (Fig. 8b), and hemlock: sugar maple ratios tend to be slightly higher at M1, M3, and M4 than they are after $2000 \mathrm{yr} \mathrm{BP}$ (Fig. 9). It is difficult to know exactly what the composition of the hardwood stands was at this time, but only M4a seems similar to the hemlock stands in analogs, ordinations, and ratios of hemlock: sugar maple pollen from 3000 to $2000 \mathrm{yr}$ BP. The other three maple stands have low hemlock: sugar maple ratios (generally <3) for the last 2000-3000 yr (Fig. 9).

$\mathrm{M} 2 \mathrm{a}$ assemblages begin to resemble surface pollen assemblages from modern hardwood forest $\sim 2000 \mathrm{yr}$ BP (Fig. 7b), when pine pollen percentages level off at modern levels and birch, hemlock, and sugar maple percentages all rise (Fig. 6). Hemlock pollen reaches a peak $\sim 1000 \mathrm{yr}$ ago (Fig. 6), when fossil levels have analogs from maple, mixed, and hemlock stands (Fig. $7 b$ ), suggesting a mixed stand (Calcote 1998). Hemlock-pine analogs weaken after $1000 \mathrm{yr}$ BP, with analogs for maple and mixed stands continuing. This hollow is close to the edge of the modern maple patch (Fig. 2); M2b, from the other side of the maple patch, shows stronger analogs to modern maple stands (Fig. 7b) and a CVA trajectory similar to M2a for the last 1000 years with increasing maple dominance (Fig. 8b). Hemlock : sugar maple ratios of about three for the last 2000 years indicate maple has been abundant relative to hemlock throughout the record.

M1 and M3 become hardwood stands $\sim 1000-800$ yr ago (Fig. 7b), also accompanied by a decrease in pine pollen percentage and an increase in birch and sugar maple (Figs. 5 and 6). Hemlock pollen percentages remain fairly constant in $\mathrm{M} 1$, declining at $\mathrm{M} 3$ in the last several hundred years. M4a has few good an- 

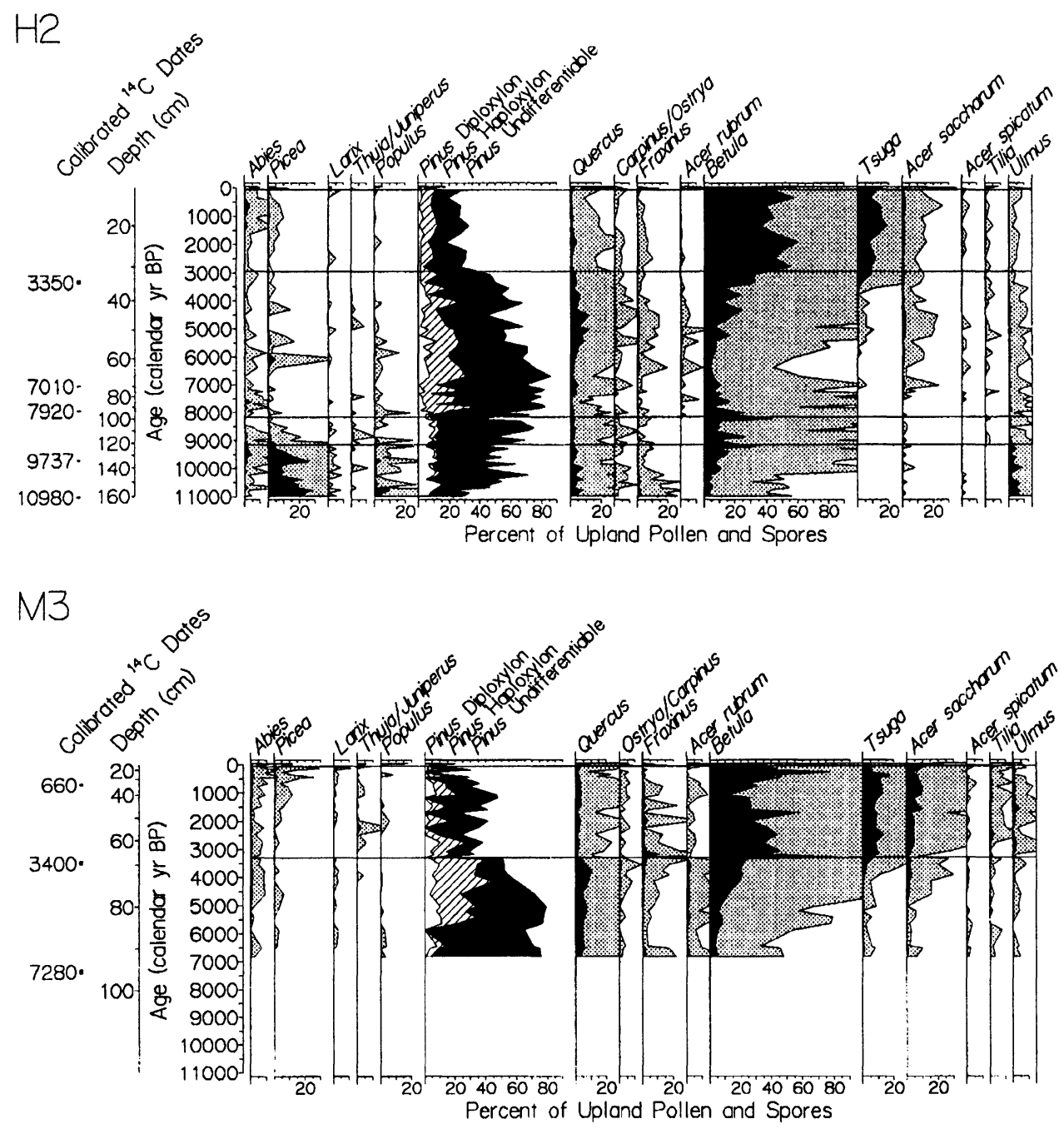

FIG. 5. Pollen diagrams for $\mathrm{H} 2$ and $\mathrm{M} 3$, showing pollen percentages (of total upland pollen) plotted against calibrated ${ }^{14} \mathrm{C}$ age of the sediment. Charcoal concentrations are shown at the right-hand side of the diagram (on facing page).

alogs, but $\sim 600$ yr ago its analogs shift toward a maple stand (Fig. 7 and Fig. 9). There is a thick layer of woody debris in the sediment $(15-33 \mathrm{~cm}, 500-1000$ yr) below which analogs indicate a pine-hemlock stand. Above this layer the pollen assemblages have analogs in maple forest. This layer of debris was so continuous across the hollow that we could not find a spot to collect a core that did not include debris, suggesting a large windthrow. M4a seems to be unique among these sites in that it was a hemlock stand but became a hardwood stand. This change appears to have occurred following a disturbance. M4b, however, seems to have been a mixed stand, according to hemlock : sugar maple ratios. For reasons that are not clear, this site has no strong analogs throughout its history (Fig. 7b).

\section{Discussion}

\section{Vegetation history}

The four hemlock stands have similar vegetation histories. The three hollows that began collecting sediment before $5000 \mathrm{yr}$ BP were surrounded by pine stands between 6000 and $5000 \mathrm{yr}$ ago, followed by a period when several stands had a large component of maple and/or oak. This period seems to have lasted $\geq 1000 \mathrm{yr}$ at some stands, roughly synchronous with the mid-Holocene warm period in southern Wisconsin and eastern Iowa (Winkler et al. 1986, Baker et al. 1992). Hemlock invaded two stands $-3400-3200 \mathrm{yr}$ ago and may not have invaded the other three for another 600-800 yr.

The history of the maple stands appears to be more variable and is less well understood. All four have pe- 


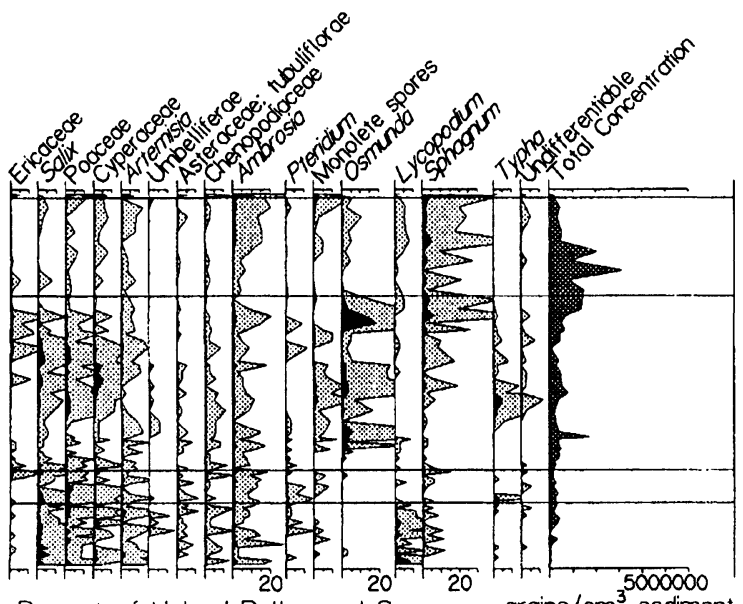

Percent of Upland Pollen and Spores grains $/ \mathrm{cm}^{3}$ sediment

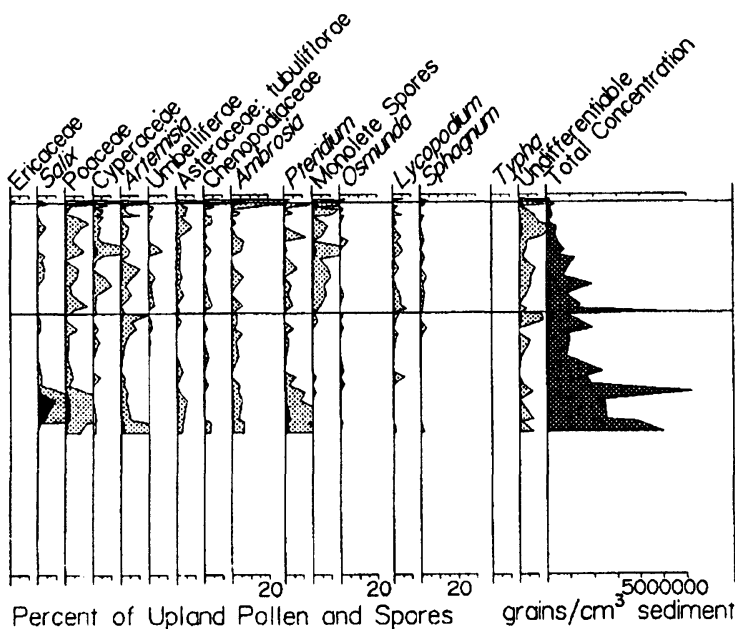

FIG. 5. Extended.
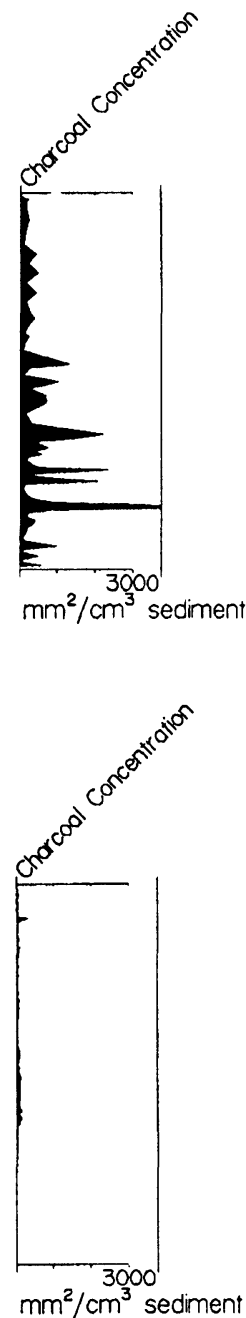

riods of $>1000 \mathrm{yr}$ when they have few or no strong analogs among our surface samples. Even the two hollows that began accumulating sediment before $5000 \mathrm{yr}$ BP have fewer strong analogs to pine stands than did the hemlock stands. It is difficult to evaluate whether the maple-oak shift seen in the hemlock stands was as prevalent in the maple stands since only two of these stands have sedimentary records through this period. One stand had no strong analogs at the time, but pollen percentages indicate that maple has been abundant in the stand for the last $5000 \mathrm{yr}$. The other seems to shift from pine to more abundant maple and/or oak, but it does not shift back to being a pine stand. Like all the maple stands, it loses all analogs during the period when hemlock is invading nearby stands. Although we do not understand the species composition of these stands at the time of regional hemlock expansion, it seems certain that it was different from the pine stands around the four hemlock hollows. The same is true of the period after $3000 \mathrm{yr} \mathrm{BP}$, when they were clearly different from the hemlock-pine forests that characterized the stands near the hemlock hollows. As the hemlock-pine stands changed to hemlock stands at various times, forests around the maple hollows began to resemble modern maple stands at various times over the last $1000 \mathrm{yr}$.

\section{Timing of invasion}

Pastor and Broschart's (1990) GIS analysis of Sylvania forests demonstrates that hemlock stands are frequently associated with lowland conifer bogs. Barnes (1991) also noted that hemlock seedlings are abundant in bogs, and he suggested that hemlock tends to spread from bogs onto uplands. It was a logical extension of this idea for Frelich et al. (1993) to suggest that hemlock might have invaded wet sites near bogs first, later expanding onto drier soils after the climate had become less limiting. Recent work by Brugam and Johnson 

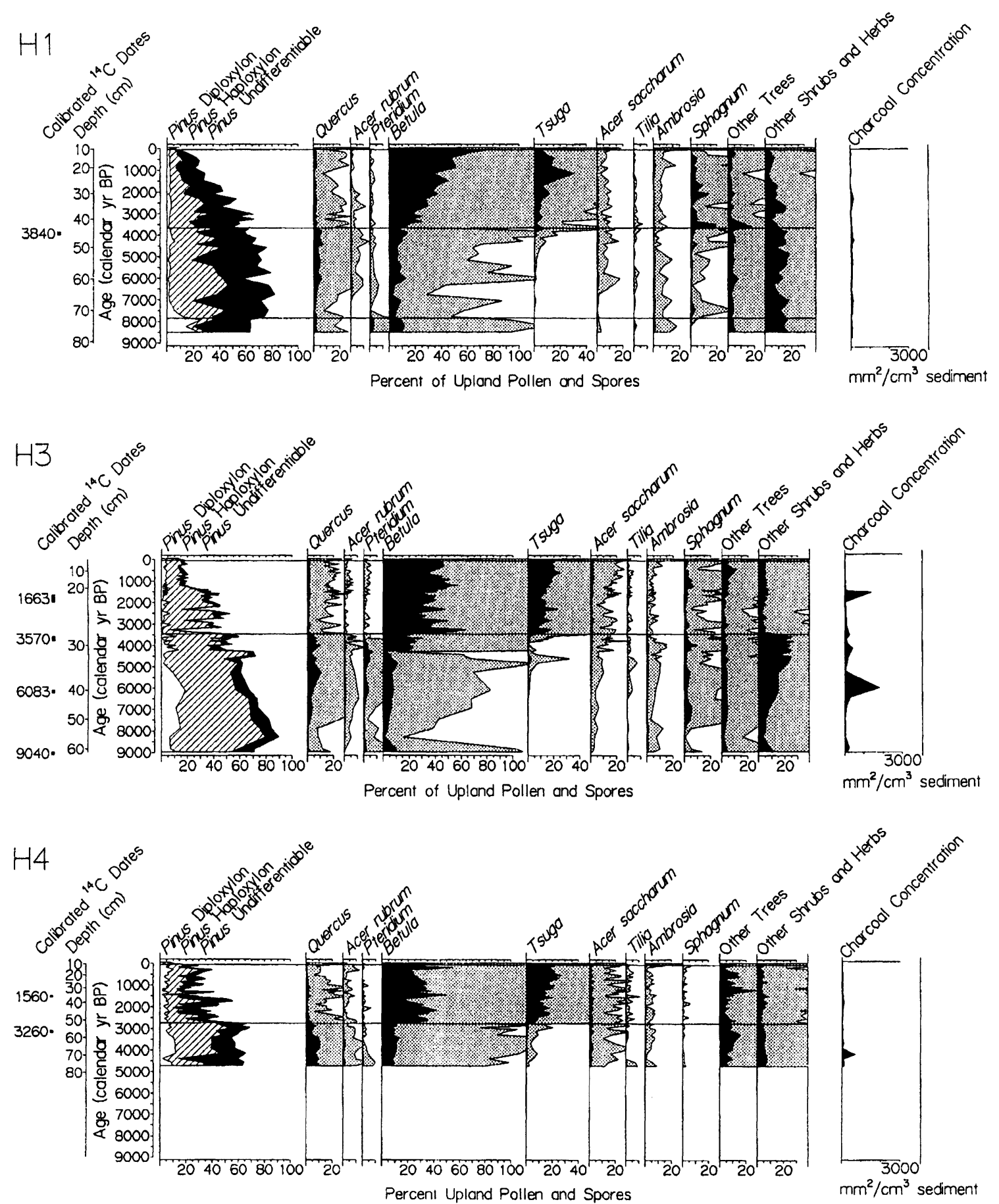

FIG. 6. Simplified pollen diagrams for hollows from the other six stands (H1, H3, and H4, and M1, M2, and M4) showing major pollen types plotted against calibrated ${ }^{14} \mathrm{C}$ age of the sediment.

(1997) demonstrates a rise in water table over the past $4000 \mathrm{yr}$ at Sylvania: a rapid rise between 4000 and $3000 \mathrm{yr}$ BP, and a slower rise since then. The increasing moisture was probably responsible for hemlock expansion into Sylvania between 4000 and $3000 \mathrm{yr}$ BP. The continuing increase in moisture from 3000 to the present could have resulted in the spread of hemlock to soils that were better drained.

We attempted to test the idea of initial hemlock invasion near bogs, but our results are ambiguous. Two 

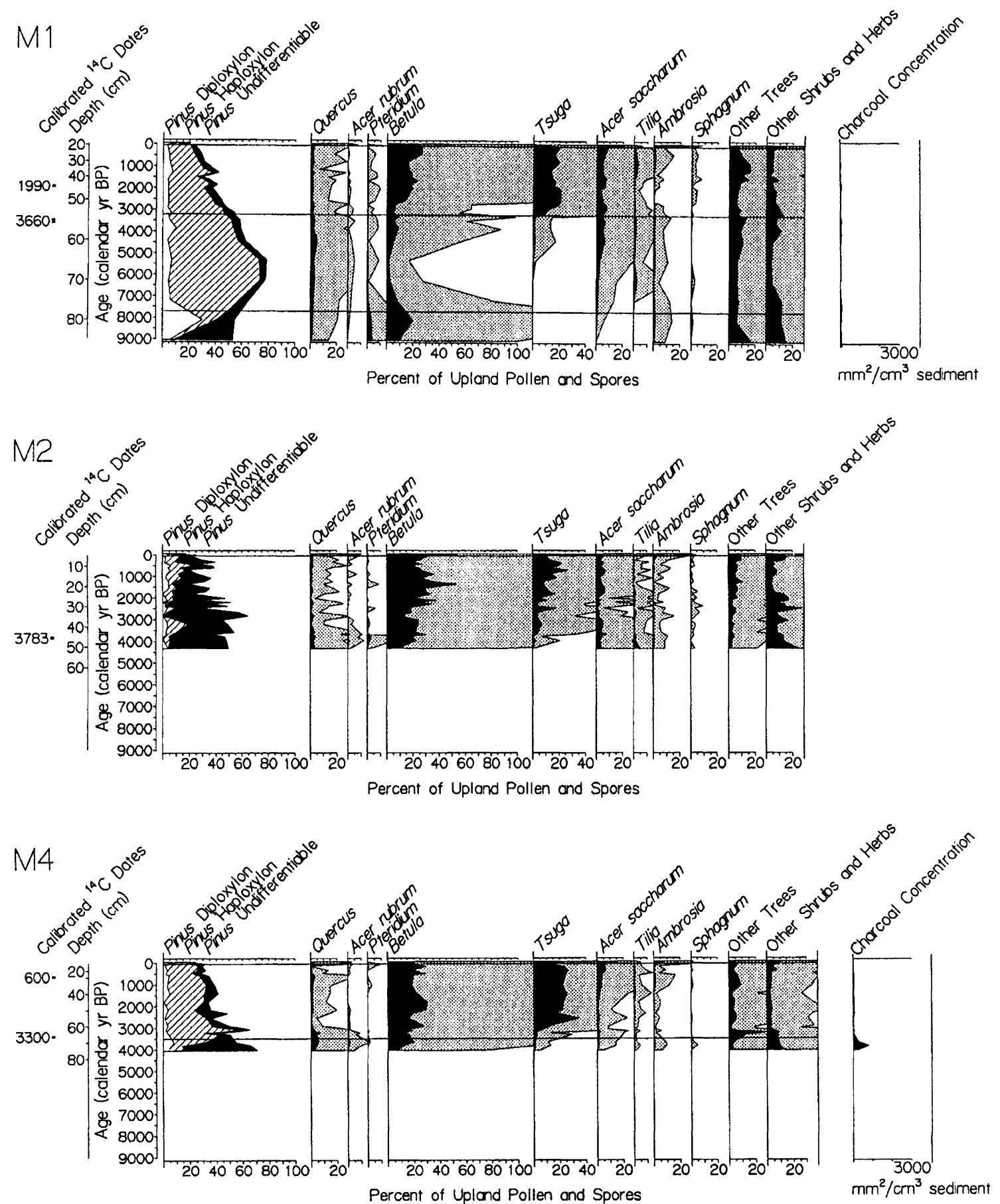

FIG. 6. Continued

of the hemlock stands, $\mathrm{H} 2$ and $\mathrm{H} 3$, are adjacent to bogs and they were invaded simultaneously between 3400 and 3200 yr ago, 800-1000 yr earlier than H4 and M4, which are distant from large bogs. However, $\mathrm{H} 1$, which is virtually surrounded by bogs today, was invaded at about the same time as $\mathrm{H} 4$ and M4. Changing climate is better reflected by subsequent events: once hemlock had invaded the forest, it increased in abundance within stands, probably at the expense of white pine, which was eventually displaced from most stands. The displacement of white pine happened at different times at different sites. Hemlock-pine analogs were replaced 


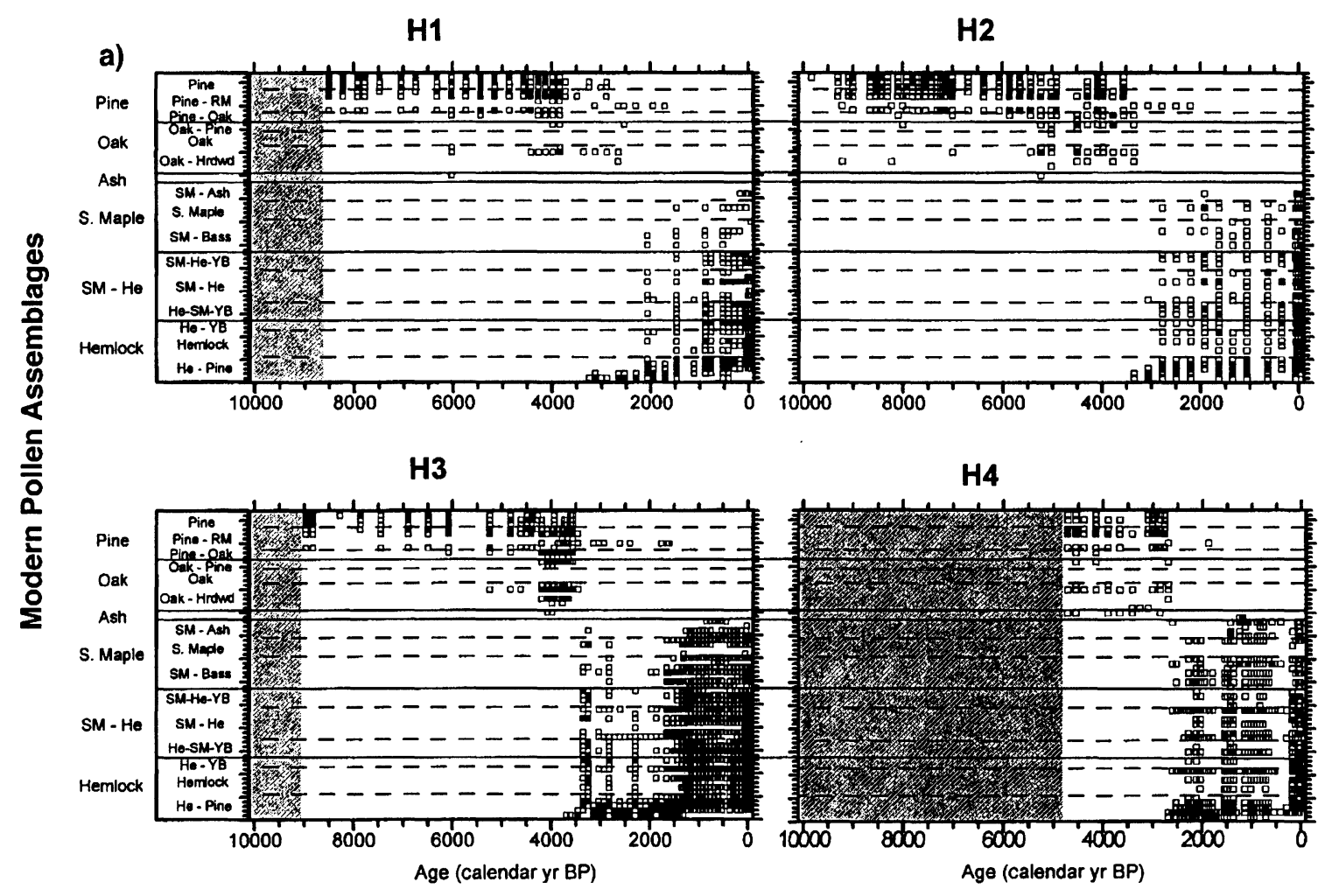

Fossil Pollen Assemblages

FIG. 7. Squared chord distances (indices of dissimilarity) of fossil pollen assemblages from (a) hemlock hollows (H1, $\mathrm{H} 2, \mathrm{H} 3$, and H4) and (b) hardwood hollows (M1, M2, M3, and M4). The $x$-axis is age of fossil pollen. Each tick on the $y$ axis is an individual pollen surface sample. Black squares $(\square)$ indicates values $<0.05$, suggesting samples from similar stand type; open squares $(\square)$ indicate weaker analogs $(\leq 1)$. The grey area on the left side of diagrams indicates a period before sediment accumulation began.

by hemlock analogs $1500 \mathrm{yr}$ ago at $\mathrm{H} 3,1500-1000 \mathrm{yr}$ ago at $\mathrm{H} 1$ and $\mathrm{H} 4$, and possibly during historic time at $\mathrm{H} 2$.

Two pollen diagrams from medium-sized lakes in Sylvania contain enough hemlock pollen $(5 \%)$ in 5000 yr-old sediment to indicate that hemlock was growing somewhere in the vicinity of Sylvania at that time (Davis et al. 1991, Brugam et al. 1997). Hemlock declined throughout its range $\sim 4800 \mathrm{yr} B P$, expanding again starting $\sim 3000 \mathrm{yr}$ ago. Our pollen diagrams record the 300()-yr-old expansion, but none of them shows clear evidence of invasion by hemlock $5000 \mathrm{yr}$ ago. This demonstrates the local nature of records in hollows, because it seems probable that hemlock persisted somewhere in or near Sylvania at low densities after the hemlock decline $4800 \mathrm{yr}$ BP. Propagules from these nearby populations were available $3000 \mathrm{yr}$ ago to invade the stands we studied. A nearby source would explain invasion of so many sites within a few centuries.

The small differences in timing of invasion that we found do not support environmental control of the invasion pattern, and they are also too small to distinguish among possible invasion scenarios such as the scattered colony model, the coalescence model (Shigesada and Kawasaki 1997), or dispersal from nearby refuge populations.

\section{Disturbance}

Several authors describe disturbance of the forest floor as a condition promoting hemlock establishment (Miles and Smith 1960, Goff 1967, Godman and Lancaster 1990). First-year hemlock seedlings are small and susceptible to desiccation (Olson et al. 1959, Coffman 1978, Barnes 1991). Bare mineral soil provides a good seed bed, because seedling roots are able to penetrate deeply enough to insure an adequate supply of moisture (Jordan and Sharpe 1967, Milfred et al. 1967, Rogers 1978, Barnes 1991). For example, seedlings germinate on north-facing, eroding slopes in Hemlock Ravine near Duluth, Minnesota, where there is a very small population of hemlock disjunct from the species boundary in Wisconsin (Calcote 1986). Fires can create conditions that promote establishment of thick stands of hemlock seedlings (Maissurov 1941). Frelich et al. (1993), for example, describe a paper birch-hemlock stand that was established following a local fire in the 


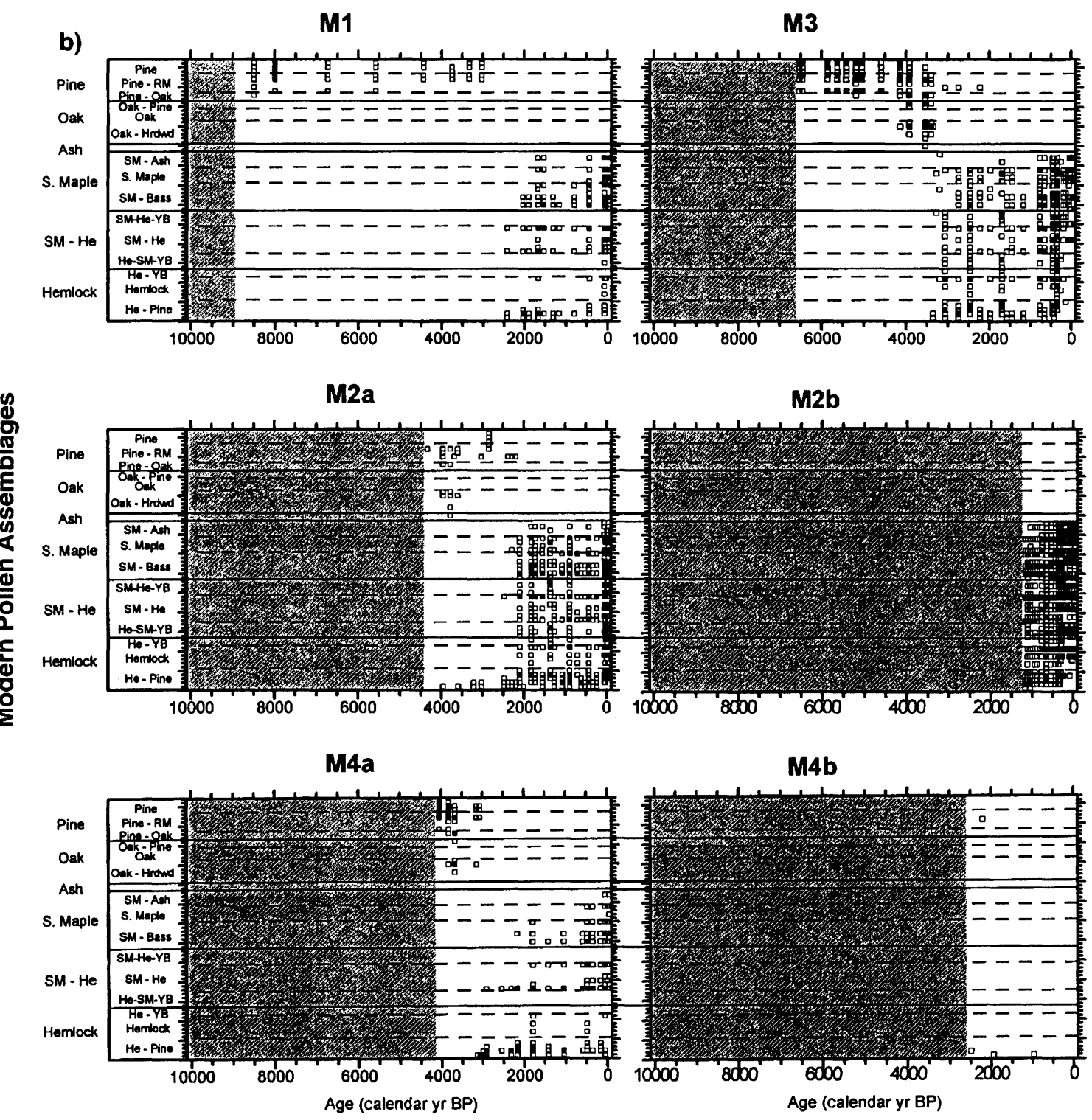

Fossil Pollen Assemblages

FIG. 7. Continued

first decade of the century along the shore of Crooked Lake in Sylvania. Ecologists emphasize, however, that these results do not imply that fire is required for hemlock regeneration (Graham 1941, Eckstein 1980). And apparently it was not required for invasion, because none of the sediment profiles we have studied contains a layer of charcoal at the level where pollen assemblages change from pine forest analogs to analogs from pine-hemlock forest. There are charcoal layers at other levels, indicating fires, but never at the level indicating hemlock invasion.

Wind storms are indicated in forest hollow sediments by layers of uncharred wood or by sharp increases in pollen abundance from shade-intolerant species such as birch. High percentages of birch pollen occur at various levels in the profiles, but never at the level where hemlock entry is evidenced. In M3 there is a peak of birch pollen $\sim 3200 \mathrm{yr}$ ago suggesting canopy opening and birch establishment. This stand was not invaded by hemlock, however.

Other authors have emphasized the importance of storms releasing advance reproduction and thus allowing hemlock to become dominant (Hough and Forbes 1943, Henry and Swan 1974). Stearns (1990) and 


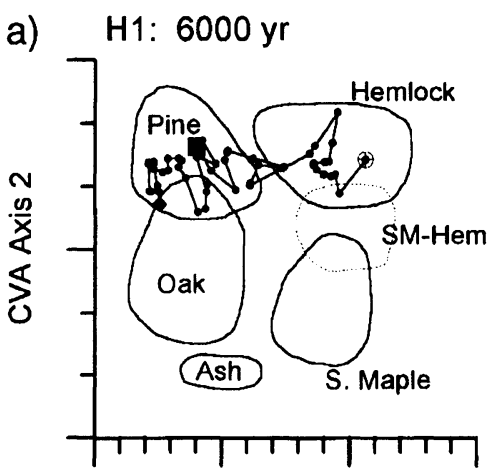

H2: $6000 \mathrm{yr}$
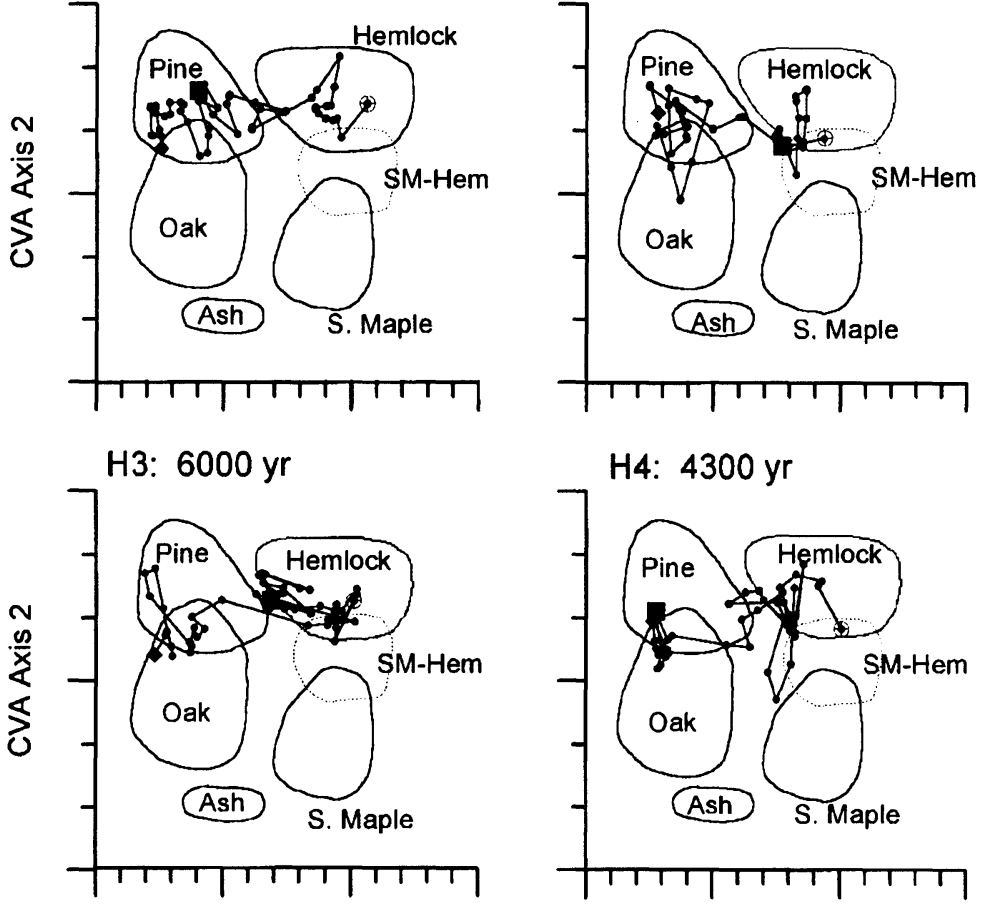

H4: $4300 \mathrm{yr}$
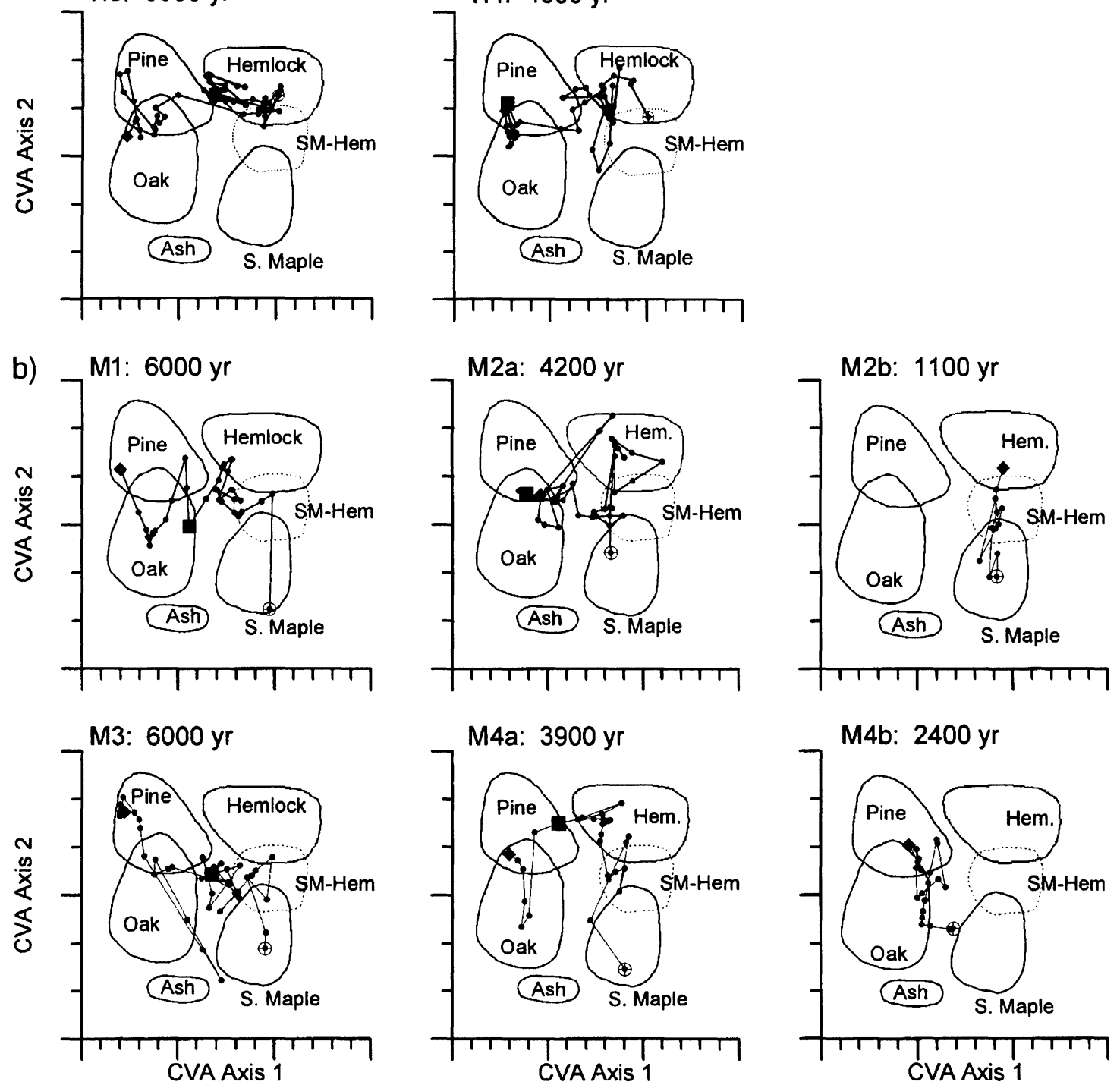

FIG. 8. Trajectories through time of pollen assemblages (a) in hemlock hollows $(\mathrm{H} 1, \mathrm{H} 2, \mathrm{H} 3$, and $\mathrm{H} 4)$ and $(\mathrm{b})$ in hardwood hollows (M1, M2, M3 and M4) projected into the CVA space defined by the 66 surface samples. Dots show the position of the trajectories interpolated to 100-yr intervals using rectangular integration (Davis 1973). The oldest sample in each series is indicated by a large diamond, and the youngest sample is indicated by a circle with a crosshair; large squares denote 3000 yr ago. Circles outline areas that include all the surface pollen assemblages from each of the six major forest community types listed in Fig. 3 

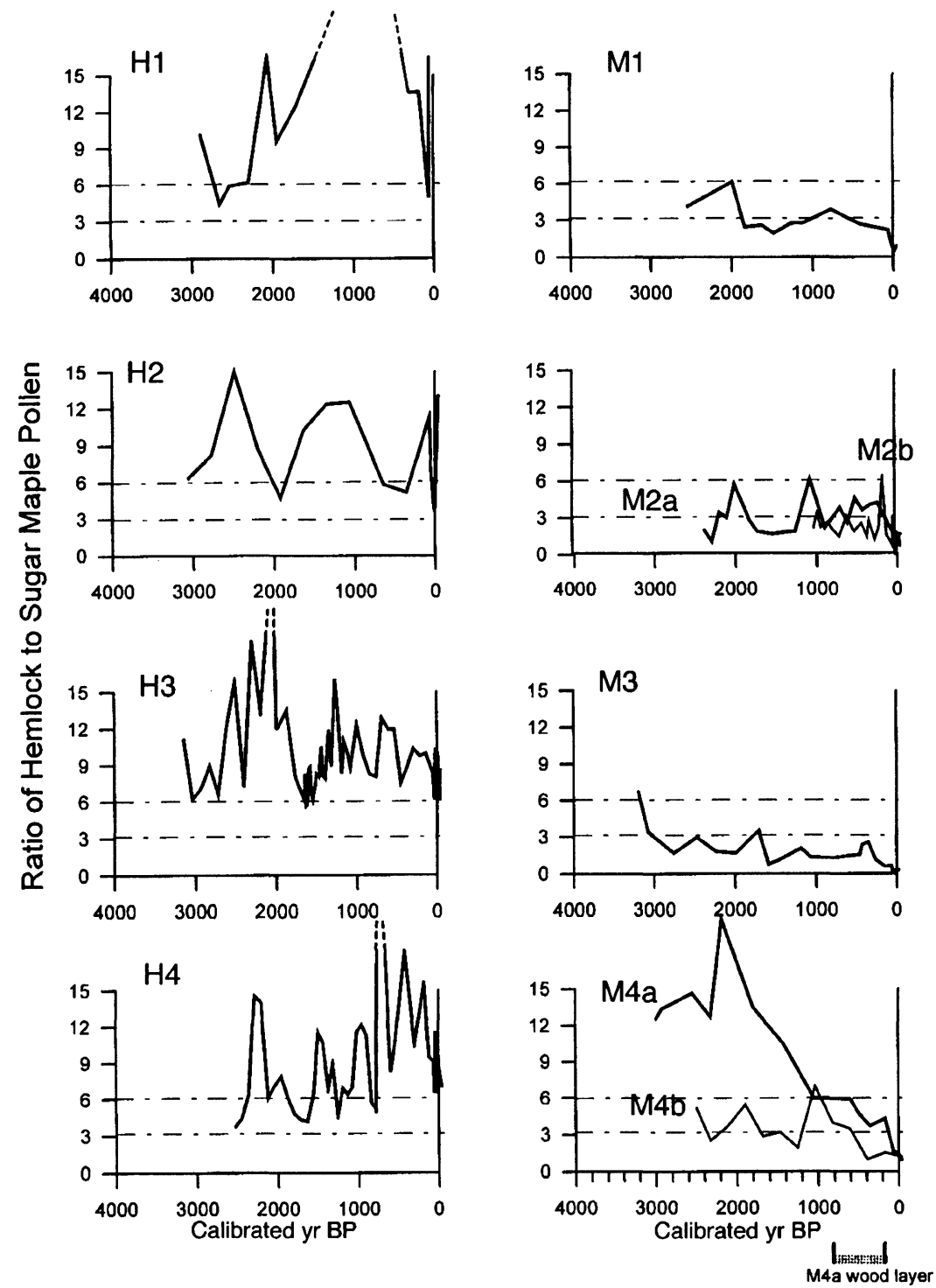

FIG. 9. Ratios of hemlock pollen to sugar maple pollen in sediment since the shift in analogs at each site to hemlockmaple stand types. Values $<3$ are characteristic of maple stands, values between 3 and 6 are characteristic of mixed stands (although a few hemlock stands fall into this range), and values $>6$ are characteristic of hemlock stands in the modern forest (Calcote 1998)

Mladenoff and Stearns (1993) hypothesize that storms (perhaps followed by fire) were numerous during the Little Ice Age AD 1450-1850, resulting in the establishment of many of the hemlock stands found in the Upper Great Lakes region today, whereas our results suggest long persistence of stands established at the time of hemlock invasion. Windstorms were probably important, however, in maintaining mixed hemlockwhite pine forests for thousands of years. There is sufficient light under white pine for hemlock to regenerate, but not under hemlock for white pine regeneration, so, in the absence of disturbance, succession could lead to hemlock dominance. However, even the young white pine in the forest today project several meters above the hemlock canopy. In the original forest the very large white pine must have created huge gaps when they blew down, with sufficient light for white pine establishment.

Windstorms that open small gaps in the forest canopy are important for hemlock accession to the canopy today (Frelich and Lorimer 1991). Catastrophic storms, however, like the Flambeau downburst in 1977 (Dunn et al. 1983) may convert hemlock stands to maple stands. This transition frequently occurs following clearcutting (Hix and Barnes 1984, Davis et al. 1996) or following clearcutting, fire, and land clearance (Eck- 
stein 1980). Analysis of tree ages in a mixed stand on Plot C at Sylvania documents a shift in abundance from hemlock to maple following windstorms during the 1930s (Parshall 1995). The best evidence for catastrophic windthrow that we have found is the layer of wood at 15-33 cm depth in M4, deposited sometime between 500 and $1000 \mathrm{yr}$ BP. No other core discussed in this paper has such a thick layer of wood, apparently representing more than one $\log$. Sediment associated with the wood has no modern analogs, possibly because it was deposited in a large opening, or because it is a mixture of sediment of several different ages. Pollen in the sediment below the wood layer is similar to surface samples from hemlock-pine forest, and pollen in sediment above it is similar to surface samples from maple forest. The evidence is suggestive that forest surrounding the hollow was converted from a hemlockpine stand to a maple stand by catastrophic windthrow, but a definitive conclusion awaits further study.

\section{Invasibility of resident forest communities}

At the time of hemlock invasion, forest stands that were invaded resembled modern white pine stands, whereas stands that were not invaded, at least by appreciable numbers of hemlock, appear to have resembled oak forest or oak forest with abundant maple. Apparently the forest was patchy, and the patchy distribution of invasible stands influenced the pattern of invasion.

One possible interpretation of the preferential invasion of pine stands involves differences in the physical environment. White pine might have been growing in wetter sites than oak, because white pine is tolerant of a much wider range of substrate conditions, growing in both wet and dry sites (Curtis 1959). If hemlock invaded wet sites by preference, it likely would have been invading white pine stands. Neither Frelich et al. (1993) nor Pastor and Broschart (1990) were able to demonstrate environmental differences between upland hemlock and maple patches, but conditions could have been different 3000 years ago.

A second interpretation involves differences in the biotic environment. Both white pine and oak form an open canopy with sufficient light on the forest floor for hemlock growth (Canham et al. 1994). However, white pine forest may have provided a better seedbed for hemlock than oak or maple stands. Hemlock seedlings are reportedly unable to penetrate hardwood leaf litter, and they can be smothered by leaf litter if they are buried during the first year or two when they are very small (Eckstein 1980). Rotted logs are a frequent site for establishment. Seedlings on a decaying log soon have an extensive root system within the log running its length in a search of moisture, and several authors describe wood and humus as sites for mycorrhizae (Harlow 1900, Lloyd 1900, Stearns 1951). In the Sylvania region today hemlock seedlings are most frequently seen in moist, acid, forested swamps, where they usually grow on moss-covered decaying logs (Westveld 1933, Rogers 1978, Davis et al. 1986, Barnes 1991). In the absence of frequent ground fires, logs on the forest floor might be more abundant in a white pine stand than in an oak-maple stand, where litter turnover rates are higher (Pastor et al. 1984).

The feedbacks that prevent hemlock establishment beneath sugar maple canopies today have not been identified with certainty, but greater availability of soil nitrate, higher light in spring, and greater soil moisture may promote vigorous growth of sugar maple seedlings that outcompete hemlock (Ferrari 1993). As maple and basswood became more abundant in the late Holocene, the factors preventing hemlock establishment today may have become more effective in excluding hemlock from these stands. It seems possible that somewhat similar feedbacks could have been in place $3000 \mathrm{yr}$ ago in some of the stands, e.g., the forest surrounding M1, which has unusually high percentages of sugar maple pollen.

\section{CONCLUSIONS}

Our studies of four hemlock stands and a former hemlock stand show that stand invasion by hemlock established five hemlock-dominated patches in the forest. Invasion by hemlock $\sim 3000$ yr BP took place within a few centuries, but did not require disturbance. Instead hemlock establishment was sensitive to the species composition of the resident forest. Hemlock invaded stands that were dominated by white pine, and did not invade stands where hardwoods were more abundant.

Once hemlock had invaded a forest stand, it maintained its dominance for thousands of years. As the climate changed, hemlock increased in abundance within the stands where it was growing, displacing the resident white pine at many sites. These results are of interest because ecologists have pondered the patchy distribution of hemlock on the landscape for many years and speculated about both the origin and fate of forests dominated by hemlock. Curtis (1959) notes the low densities of seedlings and saplings in hemlock stands and speculates that hemlock forest will eventually succeed to sugar maple forest. Anderson and Loucks (1979), Frelich and Lorimer (1985), and Alverson et al. (1988) attribute poor hemlock recruitment to increased deer populations since logging, implying that in the absence of deer the stands would persist, an opinion shared by Lutz (1930) and Graham (1941). Several ecologists have speculated that hemlock stands originate following disturbances (Hough and Forbes 1943, Stearns 1990), whereas our results show that unusual events were not required for the establishment of hemlock-dominated forest patches.

Maple-dominated stands have at least two origins. Some are descended from forest stands that were not invaded by hemlock. As the climate became more moist during the late Holocene, these forest patches accu- 
mulated increasing numbers of sugar maple and basswood trees at the expense of oak, coming to resemble modern maple stands at times that vary from stand to stand: $1000 \mathrm{yr}$ BP in one stand, $500 \mathrm{yr}$ BP in another. Several show a sharp increase in sugar maple during the historic period. This may represent human disturbance, or a response to recent changes in climate. A second category of maple stand (we have only one example) was a hemlock stand converted within the past 1000 years to a maple stand, apparently following disturbance.

The increasingly moist climate during the late Holocene favored hemlock, allowing it to increase in abundance within hemlock-pine forests. The change in climate also favored other northern hardwoods, such as sugar maple and basswood, which compete strongly with hemlock. These species increased in abundance within areas of the forest where hemlock was not growing until these patches came to resemble modern maple stands. Although feedbacks on recruitment appear sufficient to maintain this mosaic of stands at present (Frelich et al. 1993), a complex history involving a variety of processes is responsible for the mosaic origin.

\section{ACKNOWLEDGMENTS}

This work has been supported by the National Science Foundation, Grants BSR8615196 (to M. B. Davis and J. Pastor), BSR8916503 (to M. B. Davis), and DEB9221371 (to M B. Davis). The manuscript was improved as the result of helpful criticism from James Clark, George Jacobson, Sara Hotchkiss, Tim Parshall, and an anonymous reviewer. We thank Christine Douglas for careful pollen counts from several sites and for drafting figures. We gratefully acknowledge the United States Forest Service for permission to study the forests and hollows in the Sylvania Wilderness.

\section{Literature CITED}

Aaby, B. 1988. The cultural landscape as reflected in percentage and influx pollen diagrams from two Danish ombrotrophic mires. Pages 209-228 in H. H. Birks, J. J. B. Birks, P. E. Kaland, D. Moe, editors. The cultural landscape: past, present and future. Cambridge University Press, Cambridge, UK.

Alverson, W. S., D. M. Waller, and S. L. Solheim. 1988. Forests too deer: edge effects in northern Wisconsin. Conservation Biology 2:348-358.

Andersen, S. Th. 1970. The relative pollen productivity and pollen representation of north European trees, and correction factors for tree pollen spectra. Geological Survey of Denmark, II. Series Number 96:1-99

1973. The differential pollen productivity of trees and its significance for the interpretation of a pollen diagram from a forested region. Pages 109-116 in H. J. B. Birks and R. G. West, editors. Quaternary plant ecology, Blackwell, Oxford, UK.

- 1988. Changes in agricultural practices in the Holocene indicated in a pollen diagram from a small hollow in Denmark. Pages 395-408 in H. H. Birks, J. J. B. Birks, P. E. Kaland, and D. Moe, editors. The cultural landscape: past, present and future. Cambridge University Press, Cambridge, UK.

Anderson, P. M., P. J. Bartlein, and L. B. Brubaker. 1994. Late Quaternary history of tundra vegetation in northwestern Alaska. Quaternary Research 41:306-315.

Anderson, R. C., and O. L. Loucks. 1979. Whitetail deer (Odocoileus virginianus) influence on structure and com- position of Tsuga canadensis forests. Journal of Applied Ecology 16:855-861

Attig, J. W., L. Clayton, and D. M. Mickelson. 1985. Correlation of late Wisconsin glacial phases in the western Great Lakes area. Geological Society of America Bulletin 96:1585-1593

Baker, R. G., L. J. Maher, C. A. Chumbley, and K. L. Van Zant. 1992. Patterns of Holocene environmental change in the midwestern United States. Quaternary Research 37: 379-389

Barnes, B. V. 1991. Deciduous forests of North America. Pages 219-344 in E. Rohrig, and B. Ulrich, editors. Temperate deciduous forests. Ecosystems of the World Vol. 7, Elsevier, Amsterdam.

Bartlein, P. J., T. Webb III, and E. Fleri. 1984. Holocene climatic change in the northern midwest: pollen-derived estimates. Quaternary Research 22:361-374.

Bergland, B. E., and M. Ralska-Jasiewiczowa. 1986. Pollen analysis and pollen diagrams. Pages $455-484$ in B. E. Berglund, editor. Handbook of Holocene paleoecology and paleohydrology. John Wiley and Sons, Chichester, UK

Birks, H. J. B., and A. D. Gordon. 1985. Numerical methods in Quaternary pollen analysis. Academic Press, London, UK

Bjorkman, L. 1996. The history of Fagus forest in southwestern Sweden during the last 1500 years. Appendix III in L. Bjorkman. The late Holocene history of beech Fagus sylvatica and Norway spruce Picea abies at stand-scale in southern Sweden. Lundqua thesis volume 39, Lund University, Department of Quaternary Geology, Lund, Sweden.

Brugam, R. B., and S. M. Johnson. 1997. Holocene lake level rise in the Upper Peninsula of Michigan, USA as indicated by peatland growth. Holocene 7:355-359.

Brugam, R. B., M. Giorgi, C. Sesvold, S. Johnson, and R. Almos. 1997. Holocene vegetation history in the Sylvania Wilderness Area of the Western Upper Peninsula of Michigan. American Midland Naturalist 137:62-71.

Calcote, R. R. 1986. Hemlock in Minnesota: 1200 years as a rare species. Thesis. University of Minnesota, Minneapolis, Minnesota, USA.

Calcote, R. R. 1995. Pollen source area and pollen productivity: evidence from forest hollows. Journal of Ecology 83:591-602

Calcote, R. R. 1998. Identifying forest stand types using pollen from forest hollows. Holocene 8:423-432.

Canham, D. D., A. C. Finzi, S. W. Pacala, and D. H. Burbank. 1994. Causes and consequences of resource heterogeneity in forests: interspecific variation in light transmission by canopy trees. Canadian Journal of Forestry Research 24: 337-349.

Coffman, M. S. 1978. Eastern hemlock germination influenced by light, germination media, and moisture content. The Michigan Botanist 17:99-103.

COHMAP members. 1988. Climatic changes of the last 18000 years: observations and model simulations. Science 241:1043-1052.

Crawley, M. J. 1987. What makes a community invasible? Pages 429--453 in S. J. Gray, M. J. Crawley, and P. J. Edwards, editors. Colonization, succession, and stability. Blackwell Scientific, Oxford, UK.

Curtis, J. T. 1959. The vegetation of Wisconsin. University of Wisconsin Press, Madison, Wisconsin, USA.

Davis, J. C. 1973. Statistics and data analysis in geology John Wiley and Sons, New York, New York, USA.

Davis, M. B. 1976. Pleistocene biogeography of temperate deciduous forests. Geoscience and Man 13:13-26.

-1981. Quaternary history and the stability of forest communities. Pages 132-153 in D. C. West, H. H. Shugart, and D. B. Botkin, editors. Forest succession: concepts and application. Springer-Verlag, New York, New York, USA. 
1987. Invasions of forest communities during the Holocene: beech and hemlock in the Great Lakes Region Pages 373-393 in A. J. Gray, M., J. Crawley, and P. J. Edwards, editors. Colonization, succession and stability. Blackwell Scientific, Oxford, UK.

Davis, M. B., T. E. Parshall, and J. B. Ferrari. 1996. Landscape heterogeneity of hemlock-hardwood forest in northern Michigan. Pages 291-304 in Mary B. Davis, editor. Eastern old-growth forests: prospects for rediscovery and recovery. Island Press, Washington, D.C., USA

Davis, M. B., M. W. Schwartz, and K. Woods. 1991. Detecting a species limit from pollen in sediments. Journal of Biogeography 18:653-668.

Davis, M. B., and S. Sugita. 1996. Reinterpreting the fossil pollen record of Holocene tree migration. Pages 181-193 in B. Huntley, W. Cramer, A. V. Morgan, H. C. Prentice, and J. R. M. Allen, editors. Past and future rapid environmental changes: the spatial and evolutionary responses of terrestrial biota. Springer-Verlag, Berlin, Germany.

Davis, M. B., S. Sugita, R. R. Calcote, J. B. Ferrari, and L. E. Frelich. 1994. Historical development of alternate communities in a hemlock-hardwood forest in northern Michigan, USA. Pages 19-39 in P. J. Edwards, R. May, and N. $R$. Webb, editors. Large-scale ecology and conservation biology. Blackwell Scientific Publications, Oxford, UK.

Davis, M. B., S. Sugita, R. R. Calcote, and L. Frelich. 1992. Effects of invasion of Tsuga Canadensis on a North American forest ecosystem. Pages 34-44 in A. Teller, P. Mathy, and J. N. R. Jeffers, editors. Response of forest ecosystems to environmental changes. Elsevier Applied Science, London, UK

Davis, M. B., K. D. Woods, S. L. Webb, and R. P. Futuyma 1986. Dispersal versus climate: expansion of Fagus and Tsuga into the Upper Great Lakes region. Vegetatio 67:93103

Drake, J. A., H. A. Mooney, F. di Castri, R. H. Groves, F. J Kruger, M. Rejmanek, and M. Williamson, editors. 1989. Biological invasions: a global perspective. John Wiley and Sons, Chichester, UK

Dunn, C. P., G. R. Guntenspergen, and J. R. Dorney. 1983. Catastrophic wind disturbance in an old-growth hemlockhardwood forest, Wisconsin. Canadian Journal of Botany 61:211-217.

Eckstein, R. G. 1980. Eastern hemlock (Tsuga canadensis) in north central Wisconsin. Wisconsin Department of Natural Resources Research Report 104

Elton, C. S. 1958. The ecology of invasions by animals and plants. Chapman and Hall, London, UK

Ferrari, J. B. 1993. Spatial patterns of litterfall, nitrogen cycling, and understory vegetation in a hemlock-hardwood forest. Dissertation. University of Minnesota, Saint Paul, Minnesota, USA.

Fitting, J. E. 1975. The archaeology of Michigan. A guide to the prehistory of the Great Lakes Region. Cranbrook Institute of Science, Bloomfield Hills, Michigan, USA

Fox, M. D., and B. J. Fox. 1986. The susceptibility of natural communities to invasion. Pages 57-66 in R. H. Groves and J. J. Burdon, editors. Ecology of biological invasions. Cambridge University Press, Cambridge, UK.

Frelich, L. E., R. R. Calcote, M. B. Davis, and J. Pastor 1993. Patch formation and maintenance in an old-growth hemlock-hardwood forest. Ecology 74:513-527.

Frelich, L. E., and L. J. Graumlich. 1994. Age class distribution and spatial patterns in an old-growth hemlock-hardwood forest. Canadian Journal of Forestry Research 24 1939-1947

Frelich, L. E., and C. G. Lorimer. 1985. Current and predicted long-term effects of deer browsing on hemlock forests in Michigan, USA. Biological Conservation 34:99120
Frelich, L. E., and C. G. Lorimer. 1991. Natural disturbance regimes in hemlock-hardwood forests of the Upper Great Lakes Region. Ecological Monographs 61:145-164.

Godman, R. M. and K. Lancaster. 1990. Tsuga canadensis (L.) Carr. Eastern hemlock. Pages 604-612 in R. M. Burns and B. H. Honkala, coordinators. Silvics of North America. Agricultural Handbook 654, U.S.D.A. Forest Service, Washington, D.C., USA

Goff, F. G. 1967. VI. Upland vegetation. Pages $60-89$ in C J. Milfred, G. W. Olsen, and F. D. Hole, editors. Soil resources and forest ecology of Menominee County, Wisconsin. University of Wisconsin Geological and Natural History Survey, Soil Sciences Division Bulletin 85. Soil Series Number 60 .

Graham, S. A. 1941. Climax forests of the upper peninsula of Michigan. Ecology 22:355-363.

Harlow, S. H. 1900. Roots of the hemlock. Journal of the New York Botanical Garden 1:100-101

Henry, J. D., and J. M. A. Swan. 1974. Reconstructing forest history from live and dead plant material - an approach to the study of forest succession in southwest New Hampshire. Ecology 55:772-783.

Hix, D. M., and B. V. Barnes. 1984. Effects of clear-cutting on vegetation and soil of an eastern hemlock-dominated ecosystem, western Upper Michigan. Canadian Journal Forestry Research 14:914-923.

Hough, A. F, and R. D. Forbes. 1943. The ecology and silvics of forests in the high plateaus of Pennsylvania. Ecological Monographs 13:300-319

Huntley, B. 1988. Glacial and Holocene vegetation history20 ky to present: Europe. Pages 341-384 in B. Huntley and T. Webb III, editors. Vegetation history. Kluwer, Dordrecht, The Netherlands.

Huntley, B., and H. J. B. Birks, 1981. An atlas of past and present pollen maps for Europe: 0-13000 years. Cambridge University Press, Cambridge, UK

Jacobson, G. L. Jr., and E. C. Grimm. 1986. A numerical analysis of Holocene forest and prairie vegetation in central Minnesota. Ecology 67:958-966.

Jordan, J. S., and W. M. Sharp. 1967. Seeding and planting hemlock for ruffed grouse cover. U.S. Forest Service Northeast Forest Experiment Station Research Paper NE-83

Lloyd, F. E. 1900. The seeds and seedlings of the hemlock, Tsuga canadensis. Journal of the New York Botanical Garden 1:97-100.

Lodge, D. M. 1993a. Species invasions: lessons for ecology. TREE 8:133-137.

1993b. Species invasions and deletions: community effects and responses to climate and habitat change. Pages 367-387 in P. M. Kareiva, J. G. Kingsolver, and R. B. Huey, editors. Biotic interactions and global change. Sinauer, Sunderland, Massachusetts, USA.

Lutz, H. J. 1930. The vegetation of Hearts Content, a virgin forest in northwestern Pennsylvania. Ecology 11:1-29.

Lynch, E. A. 1996. The ability of pollen from small lakes and ponds to sense fine-scale vegetation patterns in the central Rocky Mountains, USA. Review of Palaeobotany and Palynology 94:197-210.

Maher, L. 1963. Pollen analysis of surface materials from the southern San Juan Mountains, Colorado. Geological Society of America Bulletin 74:1485-1504.

Maissurow, D. K. 1941. The role of fire in the perpetuation of virgin forests of northern Wisconsin. Journal of Forestry 39:201-207.

Miles, M. L., and E. C. Smith. 1960. A study of the origin of hemlock forests in southwestern Nova Scotia. Forestry Chronicles 36:375-390.

Milfred, C. J., G. W. Olson, and F. D. Hole. 1967. Soil resources and forest ecology of Menominee County, Wis- 
consin. Bulletin 85, Soil Series 60. Wisconsin Geological and Natural History Survey, Madison, Wisconsin, USA.

Mladenoff, D. J., and F. Stearns. 1993. Eastern hemlock regeneration and deer browsing in the northern Great Lakes region: a re-examination and model simulation. Conservation Biology 7:889-900

Mooney, H. A., and J. A. Drake. 1986. Ecology of biological invasions of North America and Hawaii. Springer-Verlag, New York, New York, USA.

Olson, J. S., F. W. Stearns, and H. Nienstaedt. 1959. Eastern hemlock seeds and seedlings: response to photoperiod and temperature. Bulletin of the Connecticut Agricultural Experiment Station Number $\mathbf{6 2 0}$

Overpeck, J. T., T. Webb III, and I. C. Prentice. 1985. Quantitative interpretation of fossil pollen spectra: dissimilarity coefficients and the method of modern analogs. Quaternary Research 23:87-108.

Parshall, T. E. 1995. Canopy mortality and stand-scale change in a northern hemlock-hardwood forest. Canadian Journal of Forestry Research 25:1466-1478.

Pastor, J., J. D. Aber, C. A. Aber, C. A. McClaugherty, and J. M. Melillo. 1984. Aboveground production and $\mathrm{N}$ and $\mathrm{P}$ cycling along a nitrogen mineralization gradient on Blackhawk Island, Wisconsin. Ecology 65:256-268.

Pastor, J., and M. Broschart. 1990. The spatial pattern of a northern conifer-hardwood landscape. Landscape Ecology 4:55-68.

Prentice, I. C. 1980. Multidimensional scaling as a research tool in Quaternary Palynology: a review of theory and methods. Review of Palaeobotany and Palynology 31:71104

1985. Pollen representation, source area, and basin size: toward a unified theory of pollen analysis. Quaternary Research 23:76-86.

Rejmanek, M. 1989. Invasibility in plant communities. Pages 369-388 in J. A. Drake, H. A. Mooney, F. di Castri, R. H. Groves, F. J. Kruger, M. Rejmanek, and M. Williamson, editors. Biological invasions: a global perspective. John Wiley and Sons, Chichester, UK
Rogers, R. S. 1978. Forests dominated by hemlock (Tsuga canadensis): distribution as related to site and postsettlement history. Canadian Journal of Botany 56:843-854.

Shigesada, N., and K. Kawasaki. 1997. Biological invasions theory and practice. Oxford University Press, Oxford, UK

Stearns, F. W. 1951. The composition of the sugar maplehemlock-yellow birch association in northern Wisconsin. Ecology 32:245-265.

Stearns, F. 1990. Forest history and management in the Northern Midwest. Pages 107-122 in J. M. Sweeney, editor Management of dynamic ecosystems. North Central Section, The Wildlife Society, West Lafayette, Indiana, USA

Stockmarr, J. 1971. Tablets with spores used in absolute pollen analysis. Pollen et Spores 13:615-621.

Stuiver, M., and P. J. Reimer. 1993. Extended 14C data base and revised CALIB $3.014 \mathrm{C}$ age calibration program. Radiocarbon 35(1): 215-230.

Sugita, S. 1993. A model of pollen source area for an entire lake surface. Quaternary Research 39:239-244.

- 1994. Pollen representation of vegetation in Quaternary sediments: theory and method in patchy vegetation. Journal of Ecology 82:881-897.

Tsukada, M 1958 Untersuchungen über das Verhaltnis zwischen dem Pollengehalt der Oberflachenproben und der Vegetation des Hochlandes shiga. Journal of Institute of Polytechnic, Osaka City University, Japan, Series D, volume 9:217-234.

Webb, T. III. 1988. Glacial and Holocene vegetation history-20ky to present-Eastern North America. Pages 385414 in B. Huntley and T. Webb III, editors. Vegetation history. Kluwer Academic, Dordrecht, The Netherlands.

Westveld, R. H. 1933. The relation of certain soil characteristics to forest growth and composition in the northern hardwood forest of northern Michigan. Technical Bulletin 135. Michigan Agricultural Experimental Station, East Lansing, Michigan, USA.

Winkler M G. A M Swain and J E Kutzbach 1986 Middle Holocene dry period in the northern midwestern United States: lake levels and pollen stratigraphy. Quaternary Research 25:235-250. 